\title{
LEGISLATIVE INQUIRY INTO POLITICAL ACTIVITY: FIRST AMENDMENT IMMUNITY FROM COMMITTEE INTERROGATION
}

Since the seventeenth century legislators have armed committees with subpoena powers to obtain information for a variety of legislative purposes. ${ }^{1}$ One of the oldest and most controversial of the committees' functions has been investigation of government scandals and identification of persons responsible for official mismanagement. Such investigations were set back in 1880 when the Supreme Court appeared to declare them unconstitutional usurpations of the judicial power to try and punish crimes. ${ }^{2}$ But in the nineteen-twenties the Court retreated before the scholarly articles of leading members of the Bar who acclaimed Congress' exposé of the Teapot Dome Scandal. ${ }^{3}$ Impressed by the committees' long pedigree and their skill in scourging official corruption, the Court refused to question whether the actual motive of the investigators was exposure rather than legislation. 4 Backed by a judicial policy of noninterference, the committees flourished. ${ }^{5}$ Culprits identified were jailed if the legis-

1. For general treatment of the history of legislative investigating committees see Barth, Government by Investigation (1955); Dimock, Congressional Investigating Committees (1929) ; TAyzor, Grand Inguest (1955) ; Landis, Constitutional Limitations on the Congressional Power of Investigation, $40 \mathrm{HARv}$. L. REv. 153 (1926). For studies of particular investigations of politics see CARR, The House Commintre on Un-AMrerican Actuvities 1945-1950 (1952); Ogden, The Difs Comantree (1945); and the series of books published by the Cornell University Press under the editorship of Professor Gellhorn: Barretr, The Tenney Comanitree (1951) ; Chamberlatn, Loyalty and Legislative Action (1951) (Rapp-Coudert and Lusk Committees in New York); CounTryman, Un-American Activities in the State of Washington (1951); The States AND SUbversion (Gellhorn ed. 1952) (miscellaneous committees).

The term "legislative investigating committee" will be used in this Comment to mean a committee composed of federal or state legislators authorized to compel testimony on penalty of contempt. It does not include legislative committees authorized to hold hearings on pending bills but unable to compel attendance of unwilling witnesses.

2. Kilbourn v. Thompson, 103 U.S. 168 (1880).

3. E.g., Frankfurter, Hands Off the Investigations, New Republic, May 21, 1924, p. 329; Landis, supra note 1; Potts, Power of Legislative Bodies to Punish for Contempt, 74 U. PA. L. Rev. 691 (1926). Even those critical of the particular investigation praised the institution itself. E.g., Wigmore, Comment, 19 ILI. L. REv. 452 (1925).

4. McGrain v. Daugherty, 273 U.S. 135 (1927); Sinclair v. United States, 279 U.S. 263 (1928).

The actual retreat may have begun earlier in In re Chapman, 166 U.S. 661,669 (1896) (allowing hostile investigation of senator's broker), but it was not until McGrain and Sirclair, supra, that the Supreme Court announced it would not look behind the purported purpose of investigators to discover their actual goal. Long after the Chapman case federal judges still thought Kilbourn $v$. Thompson was a prohibition against hostile investigation of private persons. Ext parte Dangherty, 229 Fed. 620 (S.D. Ohio 1924).

5. In this period, protests by recalcitrant witnesses against investigation were almost 
lative power to punish contempt reached their offenses ${ }^{6}$ if it did not, committees used the weapon of denunciation and the lash of public opinion. ${ }^{7}$

The committees not only flourished; they changed markedly in both power and scope. With money, ${ }^{8}$ manpower ${ }^{9}$ and media ${ }^{10}$ at their disposal, the committees now reach a larger audience with sharper impact than ever before.

universally unsuccessful in the courts. E.g., United States v. Fleischman, 339 U.S. 349 (1950) ; United States v. Bryan, 339 U.S. 323 (1950) ; United States v. Norris, 300 U.S. 564 (1936); Jurney v. MacCracken, 294 U.S. 125 (1935) ; Barry v. United States $e x r c l$. Cunningham, 279 U.S. 597 (1928); Marshall v. United States, 176 F.2d 473 (D.C. Cir. 1949), cert. denied, 339 U.S. 933 (1950) ; Morford v. United States, 176 F.2d 54 (D.C. Cir. 1949), rev'd on other grontnds, 339 U.S. 258, second trial, 184 F.2d 864 (D.C. Cir.), cert. denied, 340 U.S. 878 (1950); Lawson v. United States, 176 F.2d 49 (D.C. Cir. 1949), cert. denied, 339 U.S. 934 (1950) ; United States v. Dennis, 171 F.2d 986 (D.C. Cir. 1948), aff'd (cert. limited to other issues), 339 U.S. 162 (1950) ; Eisler v. United States, 170 F.2d 273 (D.C. Cir. 1948), cert. dismissed as moot, 338 U.S. 883 (1949); Townsend v. United States, 95 F.2d 352 (D.C. Cir. 1938) ; United States v. Groves, 18 F. Supp. 3 (W.D. Pa. 1937); and cases cited notes 33, 42 infra. But see Ex parte Frankfeld, 32 F. Supp. 915 (D.D.C. 1940) (contumacious witness released where proceedings against him were instituted by mere employee of House Un-American Activities Committee). See, generally, TAYLOR, GRAND INQUEST 58-70 (1955).

6. In addition to their power to punish witnesses who refuse without good reason to give testimony needed by an investigating committee, see note 111 infra, legislatures may also punish as contempt efforts to disturb the order or decorum of the body and attempts to harm, bribe or defame the members of the chamber. See, generally, Potts, supra note 3, at $780,789-90$.

7. For example, in the wake of the Teapot Dome investigation three cabinet officers resigned and two persons committed suicide. Rogers, The Amirrican Senate 207 (1926), quoted in Junz, Congressional Investigating Committees, 21 Soctar RESEARCH 379, 390 n.18 (1954).

8. See N.Y. Times, Feb. 16, 1956, p. 18, col. 5 (House of Representatives appropriated $\$ 860,000$ for three probes) ; N.Y. Times, Feb. 18, 1956, p. 20, col. 1 (Senate appropriated $\$ 726,000$ for one probe). The McCarthy Subcommittee (the Permanent Subcommittee on Investigations of the Senate Committee on Government Operations) had an appropriation of $\$ 209,156.08$ in the 83rd Congress. 99 Cong. REc. 9028 (1953). State committees have also handled large sums in the past. See ChamberdaIN, op. cit. supra note 1 , at 77 ( $\$ 250,000$ budget of Rapp-Coudert Committee) ; CounTRYMran, op. cit. supra note 1 , at 162 ( $\$ 140,600$ budget of Tenney Committee).

9. The McCarthy Subcommittee had twenty-two paid employees on July 10, 1953. 99 Cong. REC. 9028 (1953). The House Un-American Activities Committee had forty-two paid employees as of June 30, 1954. 100 CoNG. REC. 13182 (1954).

10. Committees investigating political matters have often broadcast their public hearings. E.g., Christian Science Monitor, Nov. 19, 1953, p. 6, cols. 7-8 (listing Senate hearing among radio programs); Hearitgs on Commutist Party Activities in Western Pennsylvania, Permanent Subcommittee on Investigations of the Senate Committec on Government Operations [McCarthy Subcommittee], 83d Cong., 1st Sess. 1 (1953). The greatest controversy has arisen over the use of television. See TAyLoR, Grand Inguest 247-52 (1955). In one district court case a witness cited for contempt in refusing to answer questions before television cameras was acquitted on the theory that the efforts to televise the hearings were so distracting that he could not have given accurate answers. United States v. Kleinman, 107 F. Supp. 407 (D.D.C. 1952). 
They have become semi-permanent bureaucracies, ${ }^{11}$ accumulating experience ${ }^{12}$ and perfecting publicity techniques. They screen witnesses in executive session $^{13}$ to cull their most sensational testimony for later repetition to the press and camera, ${ }^{14}$ and whole investigations are produced and directed for the utmost in theatrical effect. ${ }^{15}$ Often the committees cooperate with other groups, ${ }^{16}$

11. Most investigating committees are created $a d$ hoc and last only long enough to report on one particular problem. But several committees investigating political matters have been created with indefinite tenure. California's Un-American Activities Committee lasted eight years under the same chairman. BARRETT, op. cit. supra note 1 , at 14 . The House Un-American Activities Committee has been in existence since 1938 and was made an organic part of Congress in 1945. CARR, op. cit. supra note 1, at vi. Several permanent committees of the Senate have permanent subcommittees that have made a specialty of investigating subversion. E.g., Senate Judiciary Committee's Special Subcommittee on Internal Security; Senate Government Operations Committee's Subcommittee on Investigations. See 1 U.S. Code Cong. \& Ad. News xxxv, xxxviii (1955). All Senate subcommittees have investigating powers. 60 Star. 831-32 (1946), 2 U.S.C. \$ 190(b) (Supp. 1955). The way in which the staff of the House Un-American Activities Committee conducts a regular business of investigation and expose is treated at length in CARR, op. cit. supra note 1, c. VII.

12. See, e.g., Countryman, op. cit. sutpra note 1, at 79-85 (J. B. Matthews, former research director of the Dies Committee, helped along the infant Canwell Committee in Washington State). Harsha, The Broyles Commission, in The States and Subversion 68-69 (Gellhorn ed. 1952) (liaison maintained by other fledgling state un-American activities committees with the House Committee).

13. An executive session is an official committee meeting from which the public and press are excluded. Witnesses may or may not be examined. 60 Stat. 831 (1946), 2 U.S.C. § 190 (a) (Supp. 1955). See, generally, Taylor, Grand InQUest 244-47 (1955).

14. E.g., N.Y. Times, Aug. 16, 1955, p. 1, col. 1, p. 8, col. 3. See, generally, TayLor, GRAND INQUEST 246 (1955).

Executive session questioning of hostile witnesses is sometimes used much like depositions and discovery under the Federal Rules of Civil Procedure. Witnesses who later retract their executive session testimony in public hearings may be contradicted by the committee counsel, reading their former testimony into the public session record. E.g., Hearings before the Permantent Subcommittee on Investigations of the Conmittee on Government Opcrations: Security-Government Printing Office, 83d Cong., 1st Sess. 57 (1953) (hereinafter cited as Government Printing Office Hearings).

15. For examples see CARR, op. cit. supra note 1, at 55-78; The Progressive, Apri1 1954, pp. 35-50; CoUNTRYArAN, op. cit. supra note 1, c. IV; BARRETT, op. cit. supra note 1, at 45 ; cf. N.Y. Times, Aug. 16, 1955, p. 1, col. 1, p. 8, col. 3; Aug. 17, 1955, p. 1, col. 1, p. 15, cols. 1-3; Aug. 18, 1955, p. 1, col. 1, p. 14, cols. 3-7; Aug. 19, 1955, p. 1, col. 1, p. 6, col. 2 .

16. In driving "subversives" from critical jobs, committees have cooperated with other investigating committees, The States ANd Subversion $68-69$ (Gellhorn ed. 1952), with the F.B.I., BARRETT, op. cit. supra note 1, at 27-29, with government employers, Government Printing Office Hearings, supra note 14, at 64, and with private employers, N.Y. Times, July 14, 1955, p. 1, col. 3; CARR, op. cit. supra note 1, at 257-58; Hearings on Communist Infiliration in Defense Plants before the Permanent Subcommittee on Investigations of the Senate Committee on Government Operations, 84th Cong., 1st Sess., pp. 22-23 (1955).

Often the newspapers have cooperated, e.g., BARRETT, op. cit. supra note 1, at 280 ;

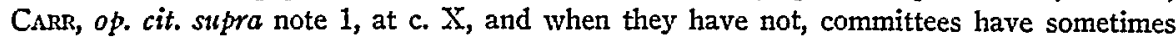
applied pressure to get cooperation, BARRETT, op. cit. supra note 1, at c. XI. Cf. Editorial, 
sharing black lists ${ }^{17}$ and informers ${ }^{18}$ in the common task of singling out individuals for public scorn. ${ }^{19}$ Even more important than the development of these new procedures has been the focus on a new sort of subject matter- the politics of private citizens. Earlier generations of investigators concentrated on government mismanagement; on the rare occasions when they made private persons their target the victim was usually attacked for bribing government officials. ${ }^{20}$ The new preoccupation with politics is of a different kind: not only bribery but "un-American" politics of every sort has become subject to hostile investigation $;^{21}$ and investigators of lobbying have apparently assumed that everything in the political process is subject to probe. ${ }^{22}$

The committees' new activities have reawakened judicial concern-this time because of the First Amendment. In the Rumely case, ${ }^{23}$ for example, Justice

N.Y. Times, Jan. 5, 1956, p. 32, col. 2 (charging persecution); TAyLOR, Grand INQUEST 80-81 (1955) (James Wechsler's charge of persecution).

17. The ubiquitous files of the House Un-American Activities Committee are described in CARR, op. cit. supra note 1, at 253-61; CounTRYMAN, op. cit. supra note 1, at 171 ; Hearings on Charges and Countercharges involving Secretary of the Army Robert T. Stevens, et al., before the Special Subcommittee on Investigations of the Senate Conmittee an Government Operations, 83d Cong., 2d Sess. 1921 (1954) (hereinafter cited as ArmyMcCarthy Hearings). Senator Mundt, a former member of the House Committee, stated that it had "five rooms of files on un-American activities." Ibid. Representative Thomas, when chairman of the Committee, listed as one of his chief objectives "continued accumulation of files and records to be placed at the disposal of the investigative units of the Government and armed services." CARR, op. cit. supra note 1, at 37-38. See Black v. Cutter Laboratories, 43 Cal. 2d 788, 795, 278 P.2d 905, 909 (1955) (discharge of private employee partly based on information from files of California Un-American Activities Committee) ; N.Y. Times, June 25, 1956, p. 1, col. 2 (black lists in entertainment industry).

18. E.g., Govermment Printing Office Hearings, supra note 14, at 2-3; Countryman, op. cit. supra note 1, at $79-85$ (J. B. Matthews) ; cf. N.Y. Times, Oct. 11, 1955, p. 38, col. 7 (letter protests Senate subcommittee's use of Paul Crouch); Aug. 19, 1955, p. 1, col. 1 (House committee hires Elizabeth Bentley as a consultant); July 14, 1955, p. 10, col. 2 (Winston Burdett).

19. Although the Supreme Court presumes investigations are not conducted for the purpose of exposure, see note 4 supra, many committees frankly announce this as a purpose. See, e.g., Army-McCarthy Hearings, supra note 17, at 1928, 1950; BARRETT, op. cit. supra note 1, at 339; TAyLOR, Grand Inguest 76 (1955).

20. Landis, stepra note 1, passim.

21. The House Un-American Activities Committee has investigated "the American Civil Liberties Union, the C.I.O., the National Catholic Welfare Conference, the FarmerLabor party, the Federal Theatre Project, consumers' organizations, various publications from the magazine 'Time' to the 'Daily Worker' ...." United States v. Josephson, 165 F.2d 82, 95 (2d Cir. 1947) (dissenting opinion).

22. See, e.g., United States v. Rumely, 345 U.S. 41, 54 (1953) (Buchanan Committee of the House of Representatives); 102 Cong. Rec. 2702-03 (daily ed. Feb. 22, 1956) (Senate committee authorized to investigate "attempts to influence improperly or illegally the Senate or any other member thereof, or any candidate therefor or any officer or employee of the Government, through campaign contributions, political activities, lobbying, or any and all other activities and practices.").

23. United States v. Rumely, 345 U.S. 41 (1953). 
Frankfurter quoted Woodrow Wilson's famous defense of the "informing function of Congress,"24 but then observed:

"President Wilson did not write in the light of the history of events since he wrote; more particularly he did not write of the investigative power of Congress in the context of the First Amendment.

“....

" $[\because]$ t cannot be denied that [a resolution giving] power to inquire into all efforts of private individuals to influence public opinion through books and periodicals, however remote the radiations of influence which they may exert upon the ultimate legislative process, raises doubts of constitutionality in view of the prohibition of the First Amendment."25

Troubled by the conflict between the First Amendment and committee practices, the courts have grown less willing to let the committees have their way, ${ }^{26}$ but to date they have not resolved the conflict. Judicial reaction to the First Amendment problem has fallen into two patterns: confusion and avoidance. The second of these is illustrated in the Rumely case, a contempt prosecution of a right-wing publisher who had refused on First Amendment grounds to tell congressional investigators the identity of his subscribers. The District of Columbia Court of Appeals agreed with the witness that Congress could not constitutionally authorize questions about such matters, ${ }^{27}$ but to avoid deciding the constitutional point the court construed the resolution authorizing the investigation narrowly, held that the question asked the witness was not pertinent, and reversed the conviction on statutory grounds. ${ }^{28}$ Hearing the case

24. Wilson, Congressional Government 297, 303 (1885).

25. 345 U.S. at 44,46 .

26. Since about 1950 the courts have found a variety of reasons for failing to convict witnesses cited for contempt because they would not disclose the political activities of themselves or other people. E.g., Bart v. United States, 349 U.S. 219 (1955) (failure of committee to rule on witness' objections); Emspak v. United States, 349 U.S. 190 (1955) (self-incrimination); Quinn v. United States, 349 U.S. 155 (1955) (same); United States v. Rumely, 345 U.S. 41 (1953) (scope of resolution); United States v. Grossman, 229 F.2d 775 (D.C. Cir. 1956) (self-incrimination); Keeney v. United States, 218 F.2d 843 (D.C. Cir. 1954) (erroneous admission of evidence) ; United States v. Kamin, 136 F. Supp. 791 (D. Mass. 1956) (pertinency) ; United States v. Deutch, N.Y. Times, Nov. 5, 1955, p. 12 , col. 4 (D.D.C.) (pleadings); United State's v. Dunham, 1 CIv. LIB. Dock. \& 340.3 (D.D.C. 1955) (self-incrimination); United States v. Metcalf, N.Y. Times, Oct. 4, 1955, p. 12, col. 6 (S.D. Ohio 1955) (pleadings); United States v. Lamont, 18 F.R.D. 27 (S.D. N.Y. 1955) (pleadings); United States v. Nelson, 103 F. Supp. 215 (D.D.C. 1952) (selfincrimination); United States v. Jaffe, 98 F. Supp. 191 (D.D.C. 1951) (same) ; United States v. Raley, 96 F. Supp. 495 (D.D.C. 1951) (same); New Hampshire v. Uphaus, 116 A.2d 887 (N.H. 1955) (service of process). Compare note 5 supra.

A similar but less striking judicial reaction occurred when Congress tried to convict witnesses for contempt because they failed to testify at the televised hearings of Senator Kefauver's committee. E.g., United States v. Doto, 205 F.2d 416 (2d Cir. 1953) (self-incrimination); Bowers v. United States, 202 F.2d 447 (D.C. Cir. 1953) (pertinency); United States v. Kleinman, 107 F. Supp. 407 (D.D.C. 1952) (too much television) ; United States v. Kamp, 102 F. Supp. 757 (D.D.C. 1952) (burden of proof not met).

27. Rumely v. United States, 197 F.2d 166, 174 (D.C. Cir. 1952).

28. Id. at $174-78$. 
on certiorari, the Supreme Court avoided the First Amendment issue in the same way. ${ }^{29}$ In other cases as well the high Court has shunned the constitutional point, ${ }^{30}$ and several astute lower court judges have followed its example. ${ }^{31}$

Two federal courts of appeal have been less evasive, but their efforts have left the First Amendment question in confusion. ${ }^{32}$ The first attempt to hurdle the constitutional barrier was the 1947 Second Circuit opinion in the Josephson case $^{33}$ affirming the contempt conviction of a private citizen who had refused to testify before the House Un-American Activities Committee in order to test the Committee's power to inquire about membership in the Communist Party. The majority reasoned that as there was no First Amendment right to secrecy about one's political affiliations, Congress could therefore impair such secrecy constitutionally. ${ }^{34}$ The opinion suggested the Constitution did not protect the timid, who alone would be deterred from free political action by the Committee's activities, ${ }^{35}$ and that in any event the deterrent effect of exposé was due to private action for which Congress was not responsible. ${ }^{36}$ The majority also refused to look behind the reasons stated in the Committee's authorizing resolution to see if its actual purpose in calling the defendant was to expose his political affiliations. ${ }^{37}$

29. United States v. Rumely, 345 U.S. 41, $47-48$ (1953). Justices Douglas and Black, protesting that the resolution could not be thus construed without doing violence to congressional intent, concurred on First Amendment grounds. Id. at 48-58.

30. E.g., Emspak v. United States, 349 U.S. 190 (1955) (decided on Fifth Amendment grounds); Tenney v. Brandhove, 341 U.S. 367 (1951) (statutory construction); Dennis v. United States, 339 U.S. 162, 950 (1950) (cert. denied on this issue); United States v. Barsky, 334 U.S. 843 (1948) (cert. denied), 339 U.S. 971 (1950) (rehearing denied); United States v. Lawson, 339 U.S. 972 (1950) (cert. denied); United States v. Marshall, 339 U.S. 933, 959 (1950) (cert. denied) ; United States v. Josephson, 333 U.S. 838 (cert. denied), 333 U.S. 858 (rehearing denied), 335 U.S. 899 (1948) (rehearing denied).

31. E.g., United States v. Kamin, 136 F. Supp. 791 (D. Mass. 1956) ; United States v. Deutch, N.Y. Times, Nov. 5, 1955, p. 12, col. 4 (D.D.C.) ; United States v. Metcalf, N.Y. Times, Oct. 4, 1955, p. 12, col. 6 (S.D. Ohio) ; United States v. Lamont, 18 F.R.D. 27 (S.D.N.Y. 1955).

32. In addition to the cases discussed in the text, a district court in the Ninth Circuit has held that the First Amendment does not prevent committee questions about Communism. United States v. Yukio Abe, 95 F. Supp. 991 (D. Hawaii 1950). In the First Circuit one district court said the same in dictum. United States v. Kamin, 136 F. Supp. 791 (D. Mass. 1956). No other federal cases on the issue have been discovered.

The only state cases found on the point are Wyman v. Sweezy, 24 U.S.L. Week 2426, 2427 (N.H. Mar. 6, 1956) (the facts here may not be the same as in the usual federal case, see note 50 infra); State v. James, 36 Wash. 2d 882, 221 P.2d 482 (1950). Cf. Nelson v. Wyman, 99 N.H. 33, 105 A.2d 756 (1954) (holding unclear); In re Coon, 44 Cal. App. 2d 531, 112 P.2d 767 (Dist. Ct. App. 1941).

33. United States v. Josephson, 165 F.2d 82 (2d Cir. 1947), cert. denied, 333 U.S. 838, rehearing denied, 333 U.S. 858, 335 U.S. 899, rehearing denied, 335 U.S. 899 (1948).

34. 165 F.2d at 92 .

35. Ibid.

36. Id. at 89 .

37. Ibid. 
A dissenting judge advocated a First Amendment limitation on the subject matter that could be investigated: subjects on which no valid legislation was possible should be immune from investigation. ${ }^{38}$ The majority's answer was that it might be necessary to investigate a subject in order to determine whether there was a clear and present danger justifying regulation. ${ }^{39}$ Moreover, they said, investigation might be in aid of legislative functions other than that of passing laws-for instance, appropriating funds. ${ }^{40}$ The court thus left the scope of congressional inquiry virtually unrestricted by the First Amendment. ${ }^{41}$

In the following year the District of Columbia Court of Appeals decided the Barsky case. ${ }^{42}$ The facts and the result were substantially identical with those of the Josephson decision, ${ }^{43}$ but the rationale was different. Where the Second Circuit had concluded that there was no abridgment of First Amendment rights, the District of Columbia Court found abridgment, ${ }^{44}$ but excused it by reasoning similar to the clear and present danger test. ${ }^{45}$ Application of the test proved tricky, however. The majority thought the "substantive evil" involved was "Communists and Communism," 46 which they found presented the requisite degree of danger. But the dissenting judge, who also invoked the clear and present danger concept, concluded that the evil at which the congressional activity was directed was "propaganda," which he thought too tame to justify interference with constitutional freedoms. ${ }^{47}$

38. Id. at 98 (Judge Clark). Cf. Quinn v. United States, 349 U.S. 155, 160-61 (1955).

39. 165 F.2d at 91 .

40. Id. at 90 .

41. See id. at 98 (dissenting opinion).

42. Barsky v. United States, 167 F.2d 241 (D.C. Cir.), cert. deriied, 334 U.S. 843, rehearing denicd, 339 U.S. 971 (1948).

43. In Barsky the leaders of the Joint Anti-Fascist Refugee Committee had wilfully failed to produce records subpoenaed by the House Un-American Activities Committee. They challenged the constitutionality of the resolution creating the committee on the ground that it permitted asking a witness if he was "a believer in Communism or a member of the Communist Party." 167 F.2d at 244. The court held the First Amendment objection unfounded, and affirmed the conviction of the witnesses for contempt of Congress. Id. at 250, 252.

44. Id. at 249.

45. The majority said that restrictive legislation must be justified by a clear and present danger, but restrictive investigation is justified "when danger is reasonably represented as potential." Id. at 247 . In a later case the court seemed to equate its test with the clear and present danger formula. Rumely v. United States, 197 F.2d 166, 174 (D.C. Cir. 1952).

46. Judge Prettyman, who wrote the opinion in Barsky, explained it this way in the later case of Rumely v. United States, 197 F.2d 166, 174 (D.C. Cir. 1952).

47. Barsky v. United States, 167 F.2d 241, 258 (1948) (Judge Edgerton). Judge Edgerton argued that the likely effect of investigating political propaganda was abridgment of First Amendment freedoms in a fashion not justified by the clear and present danger test. He also maintained that the resolution violated the First Amendment by virtue of its purpose of restraining propaganda activities. Ibid. His proposal that judges scrutinize the actual purpose of legislative investigators to determine the legality of their questions 
The Supreme Court denied certiorari in both Josephson and Barsky, ${ }^{48}$ leaving the rationales in conflict. The cases were, however, still consistent in holding that legislative inquiries into Communist affiliations did not violate the First Amendment and a number of subsequent cases have held similarly. ${ }^{49}$ This year, however, the line between questions about "Communism" and about other political activity has been challenged. The New Hampshire Supreme Court has held that a state investigating committee may ask a "Socialist" state university professor about his affiliations with the Progressive Party in $1948 . .^{50} \mathrm{In}$ sum, judicial awareness of First Amendment problems has not produced a clear line of demarcation staking out the areas of prohibited inquiry into political activity.

pointed the opposite way from the Supreme Court's earlier decisions, see note 4 stpra, and the suggestion was not adopted by other courts.

In Watkins v. United States, 24 U.S.L. Week 2329 (D.C. Cir. Jan. 26, 1956) Judge Edgerton reversed a conviction for contempt of the House Un-American Activities Committee, the opinion resting heavily on the notion that the purpose of the committee was violative of the First Amendment. But on rehearing en banc the decision was overruled. Watkins v. United States, 24 U.S.L. Week 2497 (D.C. Cir. April 23, 1956). Compare United States v. Icardi, 140 F. Supp. 383 (D.D.C. 1956), decided before the Watkins case was overruled (witness not guilty of perjury for giving false information to investigating committee since question was asked for an improper purpose).

48. Review by the Supreme Court was denied three times in Josephson, twice in Barsky. See notes 33, 42 supra.

49. E.g., Watkins v. United States, 24 U.S.L. WeEK 2497 (D.C. Cir. April 23, 1956); Marshall v. United States, 176 F.2d 473 (D.C. Cir. 1949), cert. denied, 339 U.S. 933 (1950) ; Morford v. United States, 176 F.2d 54 (D.C. Cir. 1949) ; Lawson v. United States, 176 F.2d 49 (D.C. Cir. 1949), cert. denied, 339 U.S. 934 (1950); United States v. Dennis, 171 F.2d 986 (D.C. Cir. 1948), cert. granted on other issues, 337 U.S. 954 (1949), aff'd, 339 U.S. 162 (1950) ; Eisler v. United States, 170 F.2d 273 (D.C. Cir. 1948), cert. dismissed as moot, 338 U.S. 883 (1949) ; United States v. Sacher, 139 F. Supp. 855 (D.D.C. 1956) ; United States v. Kamin, 136 F. Supp. 791 (D. Mass. 1956) (dictum); United States v. O'Connor, 135 F. Supp. 590 (D.D.C. 1955); United States v. Fitzpatrick, 96 F. Supp. 491 (D.D.C. 1951) ; United States v. Yukio Abe, 95 F. Supp. 991 (D. Hawaii 1950); State v. James, 36 Wash. 2d 882, 221 P.2d 482 (1950).

50. Wyman v. Sweezy, 24 U.S.L. Week 2426 (N.H. Mar. 6, 1956). It is not clear to what extent this case is precedent for allowing a similar question asked by a federal committee. Unlike the federal practice which makes refusal to answer congressional committee questions a misdemeanor, 11 STAT. 155 (1857), 2 U.S.C. $\$ 192$ (1952), the New Hampshire procedure under which Sweezy was punished only makes refusal to answer committee questions contempt if the committe'e has obtained a court order compelling the recalcitrant witness to answer the specific question, so that there is judicial review of the constitutionality of the question before the witness refuses to reply. N.H. REv. STAT. ANn. $\S 491: 19$ (1955).

It is not clear from the opinion or the trial record in the Sweesy case whether the witness was given an opportunity by the committee to give his testimony in secret session with a promise of its being kept confidential. Since no stress is put upon this factor in the New Hampshire Supreme Court's opinion it seems dubious that the opportunity was afforded. But in the earlier case of Nelson v. Wyman, 99 N.H. 33, 45, 105 A.2d 756, 767 (1954), the same court appeared to require the same committee to confine its questioning to executive session unless the witness desired publicity, and the court criticized the committee's practice of publishing executive session testimony of uncooperative witnesses. 
The courts' failure to state a clear First Amendment rule has had the same practical consequences as if they had decided that the amendment does not apply to legislative investigation. With the scope of the amendment beclouded as it now is, no witness can safely invoke it as a ground for refusing to testify. ${ }^{51}$ And while the Supreme Court is silent on the issue, opponents of investigating abuses cannot easily use the constitutional argument to curb them. ${ }^{52}$ Opposition is easily construed as a defense of the persons under investigation, ${ }^{53}$ for professed vigilance for constitutional rights sounds false as long as the Supreme Court itself refuses to call investigations unconstitutional.

But certain investigative activities $d o$ encroach on the area protected by the Bill of Rights, and the courts have a duty to define that area and guard against its infringement. ${ }^{54}$ To prove these points this Comment will examine the policy of the First Amendment as revealed in its wording, the history of its adoption and its past interpretation by the Supreme Court; it will show how legislative investigations of private political beliefs and activities contravene the policy of the amendment, and will suggest the manner in which the courts can and should give effect to the amendment by setting limits on the committees' activities.

The varied interpretation that the Supreme Court has given the First Amendment is such that any effort to reconcile all the holdings must ignore some of the language in the opinions. The analysis presented here is not the strongest statement of the First Amendment policy that the cases would support. Instead

51. For an example of witnesses invoking miscellaneous provisions in the Constitution in the hope that one of them would justify a refusal to answer questions about the politics of private citizens, see N.Y. Times, Aug. 19, 1955, p. 6, cols. 7-8.

52. See Editorial, N.Y. Times, Aug. 18, 1955, p. 22, col. 1.

53. See Barrett, The Tenney Conmmitte 331 (1951) ; Carr, The House CommitTEe on UN-AMrerican Activities 1945-1950, at 200 (1952); Taylor, Grand Inguest 112, 117-23 (1955) ; Press Release of Seditious Activities Investigation (Broyles) Commission of Illinois, p. 1, in cover of SPECIAL Report of CoMmitree (1949) on file in Yale Law Library. See note 16 supra, for examples of attacks by committees on hostile newspapers.

54. When the original Constitution was before the state conventions for ratification the anti-federalists opposed it for fear it would fast result in oligarchy. Their grudging support for the new scheme was won by the promise of a judge-enforced Bill of Rights to preserve popular government. See 5 WrittNGs of Thomas JeFrerson 2-3, 4, 5, 8, 20-21, 25, $45-47$ (Ford ed. 1895) ; Bloom, Hystory of the Fordiation of the Union Under the Constitution 280-82 (1940); Warren, Congress, The Constitution, and The Suprease Court 77-83 (1935).

Indeed, the Federalist Papers had promised judicial review of the constitutionality of legislation in order that the citizens might always be the masters of the Congress. THE Feneralist No. 78, at 576-80 (Hamilton ed. 1880) (Hamilton). And Madison's speech introducing the clauses which became the Bill of Rights declared that they would be enforced by judges. 1 AnNals of Congress 457 (1834). Whether or not the Founding Fathers intended judicial review at the Constitutional Convention-and the debate of scholars still goes on, see 2 Crosskey, Politics and The Constitution 938-1046 (1953); Hart \& Weschler, The Federal Courts and The Federal System 14-15 n.34 (1953)the price of anti-federalist ratification of the Constitution was a First Amendment enforced by judges. WARREN, op. cit. supra at 85; 1 ANNALS of Congress 449, 463 (1834). 
it is a description, consistent with the Supreme Court holdings, of the minimum protection that the constitutional provision affords.

\section{The Policy of the First Amendment Protection of What}

The words of the First Amendment suggest protection of three different sorts of freedoms:

a) of religion- "Congress shall make no law respecting an establishment of religion, or prohibiting the free exercise thereof";

b) of the communication of ideas-"or abridging the freedom of speech, or of the press";

c) of private political activity-"or the right of the people peaceably to assemble, and to petition the Government for a redress of grievances."

The reported debates of Congress in $1789^{55}$ dealt only with the first and last of these freedoms. ${ }^{56}$ The words "freedom of speech, or of the press" were dealt with as a facet of freedom of political activity. ${ }^{57}$ In later years, the Supreme Court recognized the free speech and free press clauses as safeguards of non-

55. The debates in the House are presented in 1 ANNals of Congress 440-68, 685-90, 730-809 (1834). There is no record of the debates in the Senate. Bloom, History of the Formation of the Union Under the Constitution 313 (1940).

56. Madison originally proposed a series of new clauses to be inserted in Art. I, $\S 9$ of the Constitution, three of which formed the basis of the present First Amendment. His phrasing suggested the modern concept of three types of freedoms. 1. ANNALs of CoNGREss 451 (1834). When the Committee of Eleven reported out proposed amendments to the House the three clauses had been rearranged to make two separate amendments-one treating religion and the other dealing with speech, press, assembly and petition. $1 i d$. at 757, 759. The two proposals were debated and passed separately and were not combined until they reached the Senate. $1 \mathrm{id}$. at 757-78; Broom, op. cit. supra note 55, at $30 \mathrm{~s}, 314$. In the debate on the amendment containing the speech, press, assembly and petition clauses there was no discussion of the right to speak or publish on nonpolitical subjects; all attention was on the topic of popular control of the federal government. 1 ANNALS of CoNGRESS 759-78 (1834); BrooM, op. cit. supra note 55, at 308-09. Representative Tucker's motion to amend the proposal to include the right of people to bind their representatives by instructions consumed most of the debate time. 1 AnNals of CoNGREss 761-76 (1834).

The primarily political connotation of the amendment was illustrated in Representative Sedwick's motion to omit mention of the right of assembly because it was self-evident that freedom of speech included the right to assemble to petition the government. $1 \mathrm{id}$. at 759 .

57. See, e.g., Del. Const. Art. $1, \S 5$ (1792), in 1 Thorpe, Amarican Charters, Constitutions, and Organic Laws 569 (1909):

"The press shall be free to every citizen who undertakes to examine the official conduct of men acting in a public capacity; and any citizen may print on any subject, being responsible for the abuse of that liberty."

PENN. Const. Art. IX, $\$ 7$ (1790), in 5 id. 3100:

"That the printing-presses shall be free to every person who undertakes to examine the proceedings of the legislature, or any branch of government, and no law shall ever be made to restrain the right thereof. ... In prosecutions for the publication of papers investigating the official conduct of officers or men in a public capacity, or 
political communication, 58 but preserved their original political stamp. ${ }^{59}$ This Comment is chiefly concerned with the relation of congressional investigations to the political segment of the First Amendment; cases bearing on the first two freedoms will be examined only as they shed light on the third. ${ }^{60}$ This aspect, as conceived by the amendment's sponsors and interpreted by the Supreme Court, protects a broadly defined political process ${ }^{61}$ embracing beliefs ${ }^{62}$ and

where the matter published is proper for public information, the truth thereof may be given in evidence...."

VT. Const. c. $1, \S \mathrm{XV}(1786)$, in 6 id. 3753 :

"That the people have a right of freedom of speech and of writing and publishing their sentiments, concerning the transactions of government-and therefor the freedom of the press ought not to be restrained."

See, generally, Chafee, Free Spezch in the United States 18 (1948); Whipple, Our ANCIENT LIBERTIEs 91-99 (1927).

58. E.g., Joseph Burstyn, Inc. v. Wilson, 343 U.S. 495 (1952) (motion pictures); Winters v. New York, 333 U.S. 507 (1948) (comic books); Thomas v. Collins, 323 U.S. 516, 531 (1945) (soliciting union members).

59. E.g., United States v. CIO, 335 U.S. 106, 121 (1948) ; Thomas v. Collins, 323 U.S. 516, 530 (1945) ; DeJonge v. Oregon, 299 U.S. 353, 363, 365 (1937); Grosjean v. American Press Co., 297 U.S. 233, 245-51 (1936); Near v. Minnesota, 283 U.S. 697, 717-23 (1931) ; cf. Beauharnais v. Illinois, 343 U.S. 250, 263 n.18 (1952); Saia v. New York, 334 U.S. 558, 561 (1948).

60. In many contexts the three aspects have identical legal consequences, and the courts find violations of the First Amendment without identifying any specific one. E.g., Joseph Burstyn, Inc. v. Wilson, 343 U.S. 495, 501, 503 (1952) ; Prince v. Massachusetts, 321 U.S. 158, 164 (1944); Murdock v. Pennsylvania, 319 U.S. 105 (1943). But on occasion the Court has distinguished the political aspect from the others to indicate that it should receive greater judicial protection, e.g., Beauharnais v. Illinois, 343 U.S. 250, 263 n.18 (1952) (dictum); Saia v. New York, 334 U.S. 558, 561 (1948) (dictum); Minersville School District v. Gobitis, 310 U.S. 586, 599 n.6 (1940) ; United States v. Carolene Products Co., 304 U.S. $144,152-53$ n.4 (1938), or to illustrate the fact that the speech, press, assembly and petition clauses fit together to make a single entity, e.g., United States v. CIO, 335 U.S. 106, 144 (1948) (concurring opinion); Thomas v. Collins, 323 U.S. 516, 530 (1945); DeJonge v. Oregon, 299 U.S. 353, 364-65 (1936).

61. E.g., 1 Annals of Congress 450, 454, 766 (1834) (Madison's explanation of his proposed amendments) ; Thomas v. Collins, 323 U.S. 516, 530 (1945) ; Board of Education v. Barnette, 319 U.S. $624,640-44$ (1943); Thornhill v. Alabama, 310 U.S. 88, 101-05 (1940).

Although the policy of the amendment is protection of the political process as a whole, the Supreme Court is authorized to vindicate that policy only when the issue is properly before it in a case or controversy involving an individual litigant's rights. Adler v. Board of Education, 342 U.S. 485 (1952) ; United Public Workers v. Mitchell, 330 U.S. 75 (1946); Federation of Labor v. McAdory, 325 U.S. 450 (1945). Where this Comment speaks of "abridgment of the political process" it would be more precise, though not more informative, to speak of abridgment of the political rights of persons entitled to participate in that process.

62. Board of Education v. Barnette, 319 U.S. 624, 642 (1943) ; cf. American Communications Ass'n v. Douds, 339 U.S. 382, 406-11 (1950) (concedes political beliefs are protected but finds the specific abridgment justified). 
their expression, ${ }^{63}$ and a wide range of activities directed toward influencing the policy of government. ${ }^{34}$

\section{Protection From Whom}

The prohibition of the First Amendment, in terms directed against "Congress," has been interpreted to prohibit interference in the political process by state governments as well..$^{65}$ It is likely that it applies to any branch or agent of either government, including legislative committees and subcommittees. ${ }^{.0}$ The amendment does not, however, restrain private action. ${ }^{67}$ Thus if both

63. Taylor v. Mississippi, 319 U.S. 583 (1943); Herndon v. Lowry, 301 U.S. 242 (1937) ; DeJonge v. Oregon, 299 U.S. 353 (1937) ; Stromberg v. California, 283 U.S. 359 (1931) ; cf. United States v. Rumely, 345 U.S. 41 (1953) ; United States v. CIO, 335 U.S. 106 (1948).

64. E.g., DeJonge v. Oregon, 299 U.S. 353 (1937) (joining political groups) ; cf. United States v. Harriss, 347 U.S. 612 (1954) (lobbying) (dictum); Saia v. New York, 334 U.S. 558 (1948) (use of candidates' sound trucks) (dictum); see also United States v. CIO, 335 U.S. 106, 143-46 (1948) (publishing union newspaper) (concurring opinion).

Earlier cases suggested that some forms of participation in the political process were not covered by the First Amendment. E.g., Jones v. Opelika, 316 U.S. 584 (1942) (commercial book sale) ; Mutual Film Corp. v. Ohio Industrial Comm'n, 236 U.S. 230 (1915) (motion pictures); Ex parte Jackson, 96 U.S. 727, 736 (1877) (use of the mails). But later decisions appear to have extended the amendment's coverage to all aspects of the process. E.g., Joseph Burstyn, Inc. v. Wilson, 343 U.S. 495 (1952) (motion pictures); Jones v. Opelika (second opinion), 319 U.S. 103 (1943) (commercial book sale); cf. Donaldson v. Read Magazine, Inc., 333 U.S. 178, 191 (1948) (use of the mails).

65. E.g., Taylor v. Mississippi, 319 U.S. 583 (1943) ; DeJonge v. Oregon, 299 U.S. 353 (1937); cf. Wieman v. Updegraff, 344 U.S. 183 (1952).

66. It is clear that the Fourteenth Amendment as it applies the First Amendment to state action forbids "abridgment" by other branches of state government as well as by the legislatures. Craig v. Harney, 331 U.S. 367 (1947) ; Pennekamp v. Florida, 328 U.S. 331 (1946) ; Bridges v. California, 314 U.S. 252 (1941). And the Fourteenth Amendment's prohibition runs against delegated legislative power as well. Board of Education v. Barnette, 319 U.S. 624, 637 (1943) ; cf. Marsh v. Alabama, 326 U.S. 501 (1946).

Federal committees might argue for a very literal construction of the word "Congress" in the First Amendment which would require the abridgment to be caused by the action of the whole Congress and not merely by a committee of one chamber. But such a construction would frustrate the purpose envisaged by the sponsors of the amendment, 1 ANNALS of CoNGress 450,454, 766 (1834), and would have no basis in policy or case law. In the only Supreme Court case discussing the issue, the Court strongly worded its intention to construe the amendment broadly, and expressly declared that the amendment applied to the federal judiciary as well as to Congress. Bridges v. California, supra, at 260, 263. One Justice has thought the amendment applicable to action by the federal executive. Joint Anti-Fascist Refugee Committee v. McGrath, 341 U.S. 123, 143 (1951) (concurring opinion by Justice Black).

67. Cf. Breard v. City of Alexandria, 341 U.S. 622, 643-44 (1951) (conviction of defendants for violation of a trespass-after-warning ordinance is not "state action" because in giving warning the state is merely acting as the agent of private homeowners). But set United States v. Paramount Pictures, 334 U.S. 131, 166-67 (1948) (dictum suggests that a private monopoly of motion picture production might violate the First Amendment if it involved restraint of what, if any, films the public will see); Marsh v. Alabama, 326 U.S. 501,509 (1946) (suggests that enforcement of private corporation rules against free speech may be government action where the corporation owns an entire town). 
governmental and private actions have combined to restrict political freedom, the amendment applies to the governmental action only if it has been a substantial factor in producing the prohibited result. ${ }^{68}$

\section{Protection Against What}

Government action in any form that interferes with or burdens freedom of political belief or activity "abridges" in the constitutional sense. ${ }^{69}$ Not only criminal statutes ${ }^{70}$ but taxation, ${ }^{71}$ licensing ${ }^{72}$ and the denial of governmental

68. In American Communications Ass'n v. Douds, 339 U.S. 382 (1950), the Court held that government action that would discourage union members from electing Communists as labor leaders abridged the political rights of the union and the leaders, but that the abridgment was constitutional. See text at notes $89-95$ infra. The Court suggested that the First Amendment would apply to government action that discouraged political effort indirectly, giving as an example a government requirement that adherents of particular political parties wear identifying arm bands. 339 U.S. at 402 . In the example and in the facts before the Court, abridgment was the result of concurrent action by both the government and private individuals. If private observers did not shun the people with arm bands, and if union members did not reject Communist leaders because of the loss of NLRB privileges, there would be no restriction of political freedom.

This seems to be the rationale of United States v. Harriss, 347 U.S. 612 (1954), and United States v. Rumely, 345 U.S. 41 (1953), where congressional efforts to compel and publicize answers about indirect lobbying were frustrated by the Court. Both decisions were nominally made on grounds of statutory construction, but the Court made it clear that its harshly restrictive construction was necessary to avoid First Amendment problems. 347 U.S. at $626 ; 345$ U.S. at $47-48$. If the First Amendment does not apply to restrictions of political freedom caused by public reactions to government publication of information obtained by compulsion, these strained constructions were unnecessary. And see Quinn v. United States, 349 U.S. 155, 161 (1955) (implies First Amendment limits the scope of legislative investigating committees). Cf. Wieman v. Updegraff, 344 U.S. 183, 191 (1952).

The case law in this area is too undeveloped to indicate the line between government stimulation of private action which is sufficiently "substantial" to invoke the First Amendment, and that which is not. But at least where testimonial compulsion by Congress is necessary to produce the resulting abridgment, the cases cited above indicate that the government's role is sufficient.

69. Early holdings of the Court limiting "abridgment" to the notion of "prior restraints" or to the common law of 1791 were superseded by Grosjean v. American Press Co., 297 U.S. 233, 248-49 (1936) ; Bridges v. California, 314 U.S. 252, 264-65 (1941). See Chafee, Free Speech in the United States 9-31 (1948).

70. E.g., Terminiello v. Chicago, 337 U.S. 1 (1949); Taylor v. Mississippi, 319 U.S. 583 (1943); Thornhill v. Alabama, 310 U.S. 88 (1940).

Criminal punishment may also lurk in the background of other types of abridgment. E.g., Thomas v. Collins, 323 U.S. 516 (1945) (punishment not for speech, but for failing to get a license before speaking); Board of Education v. Barnette, 319 U.S. 624,629 (1943) (punishment of parents who do not send children to school, coupled with denial of free schools to children who do not salute the flag); American Communication Ass'n v. Douds, 339 U.S. 382 (1950) (punishment of union leaders who falsely swear they do not believe in the use of violence, coupled with denial of NLRB services to unions whose officers have not so sworn).

71. E.g., Follett v. Town of McCormick, 321 U.S. 573 (1944) ; Murdock v. Pennsylvania, 319 U.S. 105 (1943) ; Grosjean v. American Press Co., 297 U.S. 233 (1936).

72. E.g., Joseph Burstyn, Inc. v. Wilson, 343 U.S. 495 (1952); Kunz v. New York, 340 U.S. 290 (1951) ; Schneider v. State, 30 U.S. 147 (1939). 
benefits ${ }^{73}$ have been deemed to "abridge." Nor is a formal "law" necessary so long as the cause of the restraint is official action. ${ }^{74}$

\section{Protection to What Degree}

But not every "abridgment" of the political process falls before the First Amendment: the Constitution does not provide immunity from restriction, but only requires that abridgments meet two special tests of constitutionality. ${ }^{75}$ First, the government may never curtail First Amendment freedoms at all unless some substantial public interest requires it, and even then it must use the least restrictive means compatible with its goal. This may be called the policy of least abridgment. The second requirement is that in imposing abridgments, the government may not discriminate in certain ways.

73. Government employment may be a privilege, not a right, Bailey v. Richardson, 182 F.2d 46 (D.C. Cir. 1.950), aff'd by an equally divided court, 341 U.S. 918 (1951), but denials of the privilege can abridge First Amendment freedoms, e.g., Wieman v. Updegraff, 344 U.S. 183, 191-92 (1952). Cf. Adler v. Board of Education, 342 U.S. 485, 492 (1952) (dictum); United Public Workers v. Mitchell, 330 U.S. 75, 94 (1947) (dictum).

Similarly, an alien's continued residence in the country is a privilege rather than a right, Harisiades v. Shaughnessy, 342 U.S. 580, 586-87 (1952), but discriminatory deportations would be abridgments. Cf. Kwong Hai Chew v. Gelding, 344 U.S. 590,596 n.5 (1953) (dictum); Harisiades v. Shaughnessy, supra at 591-92 (dictum).

Discrimination in affording the services of the NLRB may also be an abridgment. American Communications Ass'n v. Douds, 339 U.S. 382, 393 (1950) (dictum).

Early cases proceeded on the theory that discrimination in granting mailing privileges was not an abridgment, e.g., Ex parte Jackson, 96 U.S. 727 (1877) ; Lewis Publishing Co. v. Morgan, 229 U.S. 288, 304 (1913) (semble) ; but later decisions appear to concede that this is an abridgment that must pass First Amendment requirements, e.g., Donaldson v. Read Magazine, Inc., 333 U.S. 178, 191. (1948) ; Milwaukee Publishing Co. v. Burleson, 255 U.S. 407 (1921). Cf. Hannegan v. Esquire, Inc., 327 U.S. 146 (1945). In the light of the later decision in American Communications Ass'n v. Douds, supra, these cases would probably be treated today as examples of abridgment of freedom of communication, only justified because the test of the amendment was met.

The use of public parks and streets as a locale for public speaking is a form of government subsidy but discriminatory denial of the benefit has frequently been held an abridgment. E.g., Niemotko v. Maryland, 340 U.S. 268 (1951) ; Schneider v. State, 308 U.S. 147 (1939); Hague v. CIO, 307 U.S. 496 (1939).

For a definition of "discrimination" as used in this footnote, see text at notes 83-99 supra.

74. Although no Supreme Court decision squarely holds that the word "law" in the First Amendment embraces nonstatutory action by the federal government there is dictum to that effect in Bridges v. California, 314 U.S. 252, 260, 263 (1941), and in several cases the First Amendment, as incorporated in the Fourteenth Amendment, was held to prohibit action taken by state judges although no statute was involved. E.g., Craig v. Harney, 331 U.S. 367 (1947); Pennekamp v. Florida, 328 U.S. 331 (1946); Bridges v. California, supra.

75. In this Comment the term "abridgment" is used to describe any government action that has the effect of restricting political effort whether constitutional or not. The Supreme Court has not always used this terminology, but has sometimes reserved the term "abridgment" for actions that not only restrict freedoms but also fail to pass the constitutional tests. E.g., Breard v. City of Alexandria, 341 U.S. 622, 645 (1951). 


\section{The Policy of Least Abridgment}

The policy against unnecessary governmental restriction of First Amendment rights requires the courts to strike down restrictions unless they meet two requirements : they must be imposed for some substantial public purpose, ${ }^{76}$ and must be necessary for the purpose. ${ }^{77}$ To enforce this policy the courts first assay the goal of a given legislative action, and then determine whether means less harmful to First Amendment rights might be used to reach it. ${ }^{78}$ The courts

76. Schneider v. State, 30 U U.S. 147 (1939) (keeping streets free from littering is not a substantial purpose); cf. Jamison v. Texas, 318 U.S. 413 (1943) (same) ; Lovell v. Griffin, 303 U.S. 444 (1938) (same). See also Dennis v. United States, 341 U.S. 494, 508-09 (1951), where the Court stated that the lack of a substantial purpose for imposing abridgment was the explanation of the earlier decisions in Cantwell v. Connecticut, 310 U.S. 296 (1940) (purpose to protect the public from fraud and crime by door-to-door peddlers), Martin v. City of Struthers, 319 U.S. 141 (1943) (purpose to protect house-holders' quiet and privacy), Board of Education v. Barnette, 319 U.S. 624 (1943) (purpose to promote loyalty to the government), Thomas v. Collins, 323 U.S. 516 (1945) (purpose to protect workers from fraudulent solicitations), Marsh v. Alabama, 326 U.S. 501 (1945) (purpose to preserve owner's exclusive use of private property); of. Niemotko v. Maryland, 340 U.S. 268, 273-82 (1951) (concurring opinion) (same; also suggests that raising funds for community purposes is not a substantial purpose).

77. See cases cited in note 78 infra. The rule against vague regulations of First Amendment freedom, e.g., United States v. Harriss, 347 U.S. 612 (1954); Joseph Burstyn, Inc. v. Wilson, 343 U.S. 495 (1952); Winters v. New York, 333 U.S. 507 (1948), is a corollary of the same principle. The infirmity of vague regulations is that persons have no way of knowing whether their actions are prohibited. As a result they refrain from activity the legislature did not intend to cover rather than run the risk of prosecution. See United States v. Harriss, supra at 626; United States v. CIO, 335 U.S. 106, 153 (1948).

Similarly, the requirement that persons denied government employment on the basis of their affiliation with groups advocating political violence must have known this to be the group's purpose stems from the policy against unnecessary abridgments: a blanket denial to all members, innocent ar not, is not required to preserve the integrity of the public service. Wieman v. Updegraff, 344 U.S. 183 (1952); Adler v. Board of Education, 342 U.S. 485,492 (1952) (dictum).

78. Thus, in invalidating a state statute as an unnecessarily restrictive means to a valid goal, the Court has often suggested a permissible alternative to the legislature. E.g., Wieman v. Updegraff, 344 U.S. 183, 190 (1952) (legislature should have required scienter); Kunz v. New York, 340 U.S. 290, 293-95 (1951) (legislature should have set up standards for grant of license) ; Saia v. New York, 334 U.S. 558, 560 (1948) (legislature should have specified hours when loudspeakers were forbidden and sound level forbidden); Martin v. City of Struthers, 319 U.S. 141, 147 (1943) (legislature should have used trespass-afterwarning statute) ; Cantwell v. Connecticut, 310 U.S. 296, 307-08 (1940) (legislature should draft criminal law more specifically to restrict less activity); Thornhill v. Alabama, 310 U.S. 88, 100 (1940) (same); Schneider v. State, 308 U.S. 147, 162 (1939) (legislature should outlaw littering the streets, not distribution of handbills); Near v. Minnesota, 283 U.S. 697, 712-23 (1931) (legislature should use subsequent, not prior, restraints).

The Supreme Court has not made similar suggestions to Congress, but has sometimes virtually rewritten federal legislation to avoid unconstitutionality. E.g., United States v. Harriss, 347 U.S. 612 (1954) ; Rumely v. United States, 345 U.S. 41 (1953); United States v. CIO, 335 U.S. 106 (1.948).

Even when a statute is upheld as written, the Court usually indicates in its opinion that the restriction is as narrow as could be used to accomplish the purpose. E.g., Adler v. 
have used several verbal formulas in deciding whether restrictions were necessary. ${ }^{79}$ Sometimes the clear and present danger test has been used to summarize this general policy, ${ }^{80}$ although its original function was the narrower one of determining when speech was so likely to cause dangerous action that the speech as well as the action might be outlawed. ${ }^{81}$ The Supreme Court case law is, however, more accurately summarized by this formula: even if the end is proper, Congress cannot pursue it by means that abridge First Amendment

Board of Education, 342 U.S. 485, 490 (1952) ; Dennis v. United States, 341 U.S. 494, 505-11 (1951) ; American Communications Ass'n v. Douds, 339 U.S. 382, 405-06 (1950).

Sometimes the Court has struck down a state statute without indicating permissible means to accomplish the same goal. E.g., Board of Education v. Barnette, 319 U.S. 624 (1943); Taylor v. Mississippi, 319 U.S. 583 (1943) ; DeJonge v. Oregon, 299 U.S. 353 (1937). The opinions in these cases suggest that some legislative goals are completely barred by the First Amendment.

Choice of a particular means that abridges political freedom may often be justified where there is no less restrictive alternative that would accomplish the goal almost as well. E.g., United States v. Harriss, 347 U.S. 612, 625-26 (1954) (misrepresentative lobbying) ; Adler v. Board of Education, 342 U.S. 485, 489-90 (1952) (propaganda in schools too subtle to prevent except by scre'ening political beliefs and affiliations of teachers); Dennis v. United States, 341 U.S. 494, 510-11 (1951) (attempted revolution geared to foreign aggression).

79. There has been great disagreement among the Justices as to the proper formula for reviewing state restrictions of First Amendment freedoms. Justice Frankfurter has argued for the same formula as is applied to state restrictions of economic freedom; Justices Black and Douglas have argued that the greater specificity of the First Amendment demands a different and stricter standard of judicial review. See, e.g., Fowler v. Rhode Island, 345 U.S. 67, 70 (1953) (majority and concurring opinions) ; Beauharnais v. Illinois, 343 U.S. $250,262,268-70$ (1952) (majority and dissenting opinions); Kovacs v. Cooper, 336 U.S. 77, 89-97, 98-104 (1949) (concurring and dissenting opinion) ; FPC v. Natural Gas Pipeline Co., 315 U.S. 575, 600 n.4 (1942) (concurring opinion).

80. Dennis v. United States, 341 U.S. 494, 507-11 (1.951) ; Thomas v. Collins, 323 U.S. 516, 527 n.12, 530 (1945); Thornhill v. Alabama, 310 U.S. 88, 105 (1940).

81. Schenck v. United State's, 249 U.S. 47, 52 (1919). Compare American Communications Ass'n v. Douds, 339 U.S. 382, 396 (1950) (refusing to apply the test) ; Gitlow v. New York, 268 U.S. 652, 670-71 (1925) (same). The test was fashioned to determine the constitutionality of a statute that made speech criminal because of the tendency of such speech to cause harmful action by the audience; the test was "whether the words used are used in such circumstances and are of such a nature as to create a clear and present danger that they will bring about the substantive evils that Congress has a right to prevent." Schenck v. United States, supra at 52.

The District of Columbia Court of Appeals has tried to use the clear and present danger test to determine which questions an investigating committee witness may be compelled to answer despite the First Amendment. See text at notes 42-47 supra. But the test is inappropriate in that context. The "substantive evil" in the Schenck case was obstruction of recruiting. It had been identified by the legislature when the statute was passed. The "substantive evil" in a prosecution of a contumacious committee witness is not analogous. Not all committees are hostile, and the authorizing resolution of a friendly committee may not contemplate a "substantive evil." Even where the investigation is hostile, the resolution is often so vague that it is difficult to tell the specific evil at which it is directed. In the Barsky case, for example, the "evil" might have been identified as "Congressional ignorance"; "Communism"; "propaganda"; "disloyalty"; "attempts at revolution at home"; "Soviet aggression"; etc. See text at notes $46-47$ supra. See, generally, Congressional 
freedoms if the end could be substantially achieved without unreasonable difficulty by means that would abridge such freedom less.

\section{The Policy Against Discriminatory Abridgments}

All abridgments of the political process are discriminatory in the broad sense that they encourage some kinds of political effort and discourage others; the critical inquiry for this aspect of the amendment is the basis of discrimination..$^{82}$ By and large, as long as the least abridgment test is met, the legislature may make such distinctions as it wishes. For example, it may make distinctions based on the time, place or manner in which persons participate in the political process, ${ }^{83}$ or based on the classes of persons qualified to participate. ${ }^{84}$ But the

Investigations and First Amendnent Restrictions on the Compulsion of Testimony, 29 IND. L.J. 162, 169-72 (1954).

Moreover, use of the clear and present danger formula in this context blinds a court to the possibility of alternative legislative procedures which could accomplish the legislative goal equally well without unnecessary restrictions on political freedom.

82. In addition, the Equal Protection Clause of the Fourteenth Amendment probably applies to federal action through the Fifth Amendment. Bolling v. Sharpe, 347 U.S. 497 (1954). Cases have sometimes been vague as to whether the First Amendment nondiscrimination test or an Equal Protection Clause test were at issue. E.g., Niemotko v. Maryland, 340 U.S. 268, 272 (1951). See also cases referring to "arbitrary" abridgments of political freedom: e.g., Wieman v. Updegraff, 344 U.S. 183, 191-92 (1952); American Communications Ass'n v. Douds, 339 U.S. 382, 393, 405 (1950) (dictum) ; United Public Workers v. Mitchell, 330 U.S. 75, 100 (1946) (dictum). But discrimination may violate both the First Amendment test and the Equal Protection Clause. Fowler v. Rhode Island, 345 U.S. 67 (1953).

The two major differences between the First Amendment nondiscrimination policy and the Equal Protection Clause seem to be: (1) the First Amendment is only concerned with discrimination against political candidates and platforms, ideas, and religion, while the other clause applies to all subjects; (2) the First Amendment flatly bans certain types of discrimination without regard to their "reasonableness," e.g., United Public Workers v. Mitchell, 330 U.S. 75, 100 (1946) (dictum) whereas the Equal Protection Clause involve's consideration of the reasonableness of the categories created by the legisiature, e.g., Tigner v. Texas, 310 U.S. 141 (1940). However, when discrimination is based on race the Equal Protection Clause may also operate automatically. Cf. Brown v. Board of Education, 347 U.S. 483, 493 (1954); United Public Workers v. Mitchell, 330 U.S. 75, 94, 100 (1946) (dictum).

83. Time: Milk Wagon Drivers Union v. Meadowmoor Dairies, 312 U.S. 287, 298 (1941) (injunction of picketing for limited time is constitutional); Schenck v. United States, 249 U.S. 47, 52 (1919) (prohibition of incitement to resist draft during wartime is constitutional) ; cf. Bridges v. California, 314 U.S. 252, 269 (1941) (indefinite ban on discussion is unconstitutional).

Place: Breard v. City of Alexandria, 341 U.S. 622, 642 (1951) (ban on door-to-door peddling of literature after warning is constitutional) ; Kovacs v. Cooper, 336 U.S. 77, 85 (1949) (ban on sound trucks in certain areas is constitutional); Milk Wagon Drivers Union v. Meadowmoor Dairies, supra at 298 (ban on picketing near dairies is constitutional) ; cf. Martin v. City of Struthers, 319 U.S. 141, 146 (1943) (ban on all door-to-door peddling of literature is unconstitutional). Suggestions in earlier cases that the exercise of First Amendment freedoms in public parks and streets was immune from regulation, c.g., Schneider v. State, 308 U.S. 147, $162-63$ (1939) (streets); Hague v. CIO, 307 U.S. 
legislature cannot discriminate against a candidate urged for office or a policy advocated for government adoption. ${ }^{85}$ In regulating the form of the democratic process the legislature can go as far as the least abridgment test permits in scotching not only undesirable methods of politicking, but even the teaching of them ${ }^{86}$ or the belief in them. ${ }^{87}$ In every case, however, the court must decide whether the legislative prescription touches upon the substance rather than the form of political activity: the persons affected may not be singled out because they believe in, teach or strive for one particular candidate or government policy rather than another. ${ }^{88}$

496, 515 (1939) (parks), have been replaced by later decisions allowing such regulation as long as there is no unnecessary or discriminatory abridgment, e.g., Poulos v. New Hampshire, 345 U.S. 395, 403 (1.953) (parks) ; Cox v. New Hampshire, 312 U.S. 569, 574 78 (1941) (streets).

Manner: United States v. Harriss, 347 U.S. 612, 625 (1954) (professional direct lobbying); Dennis v. United States, 341 U.S. 494 (1951) (force and violence); Hughes v. Superior Court, 339 U.S. 460, $464-65$ (1950) (picketing) ; American Communications Ass'n v. Douds, 339 U.S. 382, 390 (1950) (political strikes); Kovacs v. Cooper, supra (loud sound trucks) ; Mabee v. White Plains Publishing Co., 327 U.S. 178, 184 (1946) (paying newspaper employees less than minimum wage); NBC v. United States, 319 U.S. 190 (1943) (radio broadcasting without a license); Associated Press v. NLRB, 301. U.S. 103 (1937) (firing editors for union affiliation); Milwaukee Publishing Co. v. Burleson, 255 U.S. 407 (1921) (inciting to crime).

84. Classes of persons discriminated against have long included people without property holdings, children, women (until the Nineteenth Amendment), aliens, nonresidents and persons who had not paid their poll taxes. See, generally, EmERson \& Harer, Polimical \& Civil Rights in the United States $249-50$ (1952). However, there is no requirement that discrimination be based solely on the competency of individuals to make an intelligent political choice. E.g., United Public Workers v. Mitchell, 330 U.S. 75 (1946) (government employees); Breedlove v. Suttles, 302 U.S. 277 (1937) (person who did not pay poll tax); cf. Ludecke v. Watkins, 335 U.S. 160, 171 (1948) (aliens in wartime). Classes of persons with more power may be singled out for more extensive regulation. E.g., United States v. Harriss, 347 U.S. 612 (1954) (professional direct lobbyists); American Communications Ass'n v. Douds, 339 U.S. 382, 405 (1950) (union leaders) ; NLRB v. Virginia Power Co., 314 U.S. 469 (1941) (employers).

85. E.g., Harisiade's v. Shaughnessy, 342 U.S. 580, 592 (1952) (dictum); American Communications Ass'n v. Douds, 339 U.S. 382, 405 (1950) (dictum) ; Kovacs v. Cooper, 336 U.S. 77, 96-97 (1949) (concurring opinion); id. at 102 (dissent); United Public Workers v. Mitchell, 330 U.S. 75, 100 (1946) (dictum) ; NBC v. United States, 319 U.S. 190,226 (1943) (dictum) ; cf. Wieman v. Updegraff, 344 U.S. 183, 191 (1952) ; Dennis v. United States, 341 U.S. 494, 556 (1951) (concurring opinion); American Communications Ass'n v. Douds, supra at 419 (concurring opinion); Hague v. ClO, 307 U.S. 496 (1938); Associated Press v. NLRB, 301 U.S. 103, 130-33 (1937). The cases cited in note 60 supra, that speak of a preferred position for the political freedom accorded by the First Amendment seem to have this policy in view; and this policy is the heart of the popular control over legislators which the First Amendment was intended to secure. 1 ANNals of CoNGRESS $759-78$ (1834).

86. Dennis v. United States, 341 U.S. 494 (1951) (conspiracy to teach violent revolution); cf. Adler v. Board of Education, 342 U.S. 485 (1952) (knowing affiliation with a group teaching violent revolution).

87. American Communications Ass'n v. Douds, 339 U.S. 382 (1950) (belief in the use of force or illegal means for political ends). See text at notes 89-97 infra.

88. Occasionally, discrimination based on political procedures may have an incidental 
The Douds case illustrates these principles. ${ }^{89}$ In that case the Supreme Court upheld the constitutionality of a federal statute denying the services of the National Labor Relations Board to any union whose officers failed to swear that they did not belong to the Communist Party and did not believe in the use of force for political ends. ${ }^{90}$ The Court, finding that the statute did abridge the political process, ${ }^{91}$ and that it passed the least abridgment test, ${ }^{92}$ decided that it did not involve a forbidden type of discrimination. ${ }^{93}$ The statute made a critical distinction between persons who believed in the use of force and violence to achieve political ends and those who did not: the belief proscribed was one about use of a political procedure, not a belief about candidates or goals of government. ${ }^{94}$ The most difficult distinction was that drawn between members of the Communist Party and all other persons. Since the Party supports candidates and policies for government, this appeared to be discrimination of the prohibited sort. Chief Justice Vinson handled the problem by finding that members of the Communist Party were pledged to improper political methods. ${ }^{95}$ By this rationale the discrimination became one based on the Party's threatened use of force and violence, rather than its candidates or platform. ${ }^{96}$

Subsequent Supreme Court cases allowing Congress to discriminate between the Communist Party and other political parties have rested on the same foundation: that the Communist Party differs from other political groups in the procedure it is committed to use to bring about adoption of its program and

discriminatory effect on substance. Such incidental discriminatory effects are unconstitutional unless necessary for the accomplishment of a proper legislative purpose. Martin v. City of Struthers, 319 U.S. 141, 146 (1943) ; Murdock v. Pennsylvania, 319 U.S. 105, 114 (1943) ; Thornhill v. Alabama, 310 U.S. 88, 104 (1940) ; cf. Lincoln Union v. Northwestern Co., 335 U.S. 525,530 (1949).

Cases involving such indirect discrimination against advocacy of particular programs for government are the most difficult for the Court. See the Douds case, discussed in text at notes 89-95 infra (discrimination against persons connected with the Communist Party); MacDougall v. Green, 335 U.S. 281 (1948) (minority party trying to get on the ballot); United States v. CIO, 335 U.S. 106 (1948) (restriction on union campaign expenditures); Colegrove v. Green, 328 U.S. 549 (1946) (urban voters protesting pro-rural gerrymander).

89. American Communications Ass'n v. Douds, 339 U.S. 382 (1950).

90. 61 Stat. 146 (1947), 29 U.S.C. \$ 159(h) (1952).

91. 339 U.S. at 393.

92. Id. at $400-02$.

93. Id. at $403,405,407-11$.

94. Id. at $406-12$.

95. Id. at 407-08. Justice Jackson, concurring, elaborated on the difference between the methods used by the Communist Party and the methods of other groups. Id. at 423-35.

96. The Court also examined two other types of discrimination in the statute: the distinction made between union leaders and other persons, and the distinction between political strikes and other methods of political effort. The first was upheld by the Court on the theory that it was not based upon the candidates or policies supported by union leaders but upon the special power they wielded to interrupt interstate commerce through strikes. Id, at 403-04. The second was upheld on the theory that Congress could if it wished outlaw strikes in interstate commerce as an improper means of political expression. Id. at $397-403$. 
candidates. ${ }^{97}$ Other cases since Douds have made clear that in imposing restraints on the political process, Congress may not discriminate between persons who support one political party rather than another so long as both parties are willing to use lawful procedures. ${ }^{98}$

In sum, the First Amendment is called into play whenever political belief or action is restricted in any manner by any governmental agency; it forbids such restrictions when they are not necessary to effect a substantial policy, or when they discriminate among candidates or among policies being urged for government adoption. ${ }^{99}$ It remains to show how the activities of legislative investi-

97. E.g., Harisiades v. Shaughnessy, 342 U.S. 580, 592 (1952) ; Adler v. Board of Education, 342 U.S. 485, 492 (1952) ; Dennis v. United States, 341 U.S. 494, 510-11 (1951).

98. Harisiades v. Shaughnessy, 342 U.S. 580, 592 (1952). In several other cases the Court has invalidated government discrimination against political groups or persons vague$1 \mathrm{y}$ associated with them, on the ground that the discrimination is "arbitrary," without making clear whether the constitutional ground was substantive due process, equal protection, or the First Amendment nondiscrimination policy. E.g., Wieman v. Updegraff, 344 U.S. 183, 191-92 (1952) ; Niemotko v. Maryland, 340 U.S. 268, 272 (1951).

99. The tests apply to the other two aspects of the amendment as well as the political one. The least abridgment test, for example, with its requirement that restrictions be no broader than necessary, see text at notes 77-79 supra, has been applied to invalidate statutes abridging communication of ideas, Joseph Burstyn, Inc. v. Wilson, 343 U.S. 495 (1952) (vague); Thornhill v. Alabama, 310 U.S. 88, 97-98 (1940) (overly broad); Grosjean v. American Press Co., 297 U.S. 233 (1936) (inappropriate type of tax), and statutes restricting the exercise of religious freedom, Board of Education v. Barnette, 319 U.S. 624 (1943); Pierce v. Society of Sisters, 268 U.S. 510 (1925).

The nondiscrimination test, see text at notes $82-88$ supra, also reaches the nonpolitical; but here the test has been applied somewhat differently. Because the relationship of the government to religion is complicated by the additional requirement that "Congress shail make no law ... respecting the establishment of religion," the nondiscrimination policy as applied to religious matters is exceedingly difficult. Not only discrimination between sects is forbidden, Niemotko v. Maryland, 340 U.S. 268 (1951), but discrimination against all religion is equally bad, Everson v. Board of Education, 330 U.S. 1, 15 (1947) (dictum). Moreover, discrimination in favor of all religion may be bad as an "establishment." Ibid; cf. Murdock v. Pennsylvania, 319 U.S. 105, 130, 139-40 (1943) (dissents argue tax exemption for religious colporteurs is an "establishment"). No comparable prohibition against government establishment of politics or the communication of ideas appears in the amendment or the case law. E.g., Associated Press v. United States, 326 U.S. 1, 19-20 (1945) (government may bring antitrust suit to promote the communication of ideas).

The nondiscrimination test has frequently been applied to the communication of ideas. Discriminations based on the speaker's time, place, mode of expression or his identity have been upheld with little difficulty. E.g., Milk Wagon Drivers Union v. Meadowmoor Dairies, 312 U.S. 287, 296, 298 (1941) (time: enjoin peaceful picketing only while overtones of past violence cling to it); Breard v. City of Alexandria, 341 U.S. 622, 642 (1951) (placc: householders' front doors) ; Hughes v. Superior Court, 339 U.S. 460, 464-65 (1950) (mode: picketing); Prince v. Massachusetts, 321 U.S. 158 (1944) (idcntity: children).

Discrimination against specific ideas, on the other hand, is generally unconstitutional, e.g., Kunz v. New York, 340 U.S. 290, 294 (1951) ; Saia v. New York, 334 U.S. 558, 56162 (1948) ; Taylor v. Mississippi, 319 U.S. 583 (1943), but four exceptions have been recognized: ideas that are libelous, obscene or profane may be singled out for restriction, Beauharnais v. Illinois, 343 U.S. 250 (1952), and ideas that are too dangerously likely to result in "substantive evils which Congress has a right to prevent" may also be discrimi- 
gating committees run into the prohibitions of the First Amendment; and then to examine what the courts can and should do about it.

\section{The Committees and the Amendment}

A hypothetical example of clearly unconstitutional investigation will illustrate the foregoing analysis of the First Amendment. A congressional committee is authorized to investigate political behavior to determine whether the minimum age for voting should be raised. The authorizing resolution has stated that the present law fosters un-American voting, and the committee has promised to reveal the names of young citizens who have unpatriotic voting records. The committee hearing is public, covered by press, radio and television. Witness $A$, whose name has been mentioned by prior witnesses, is subpoenaed to the hearing and asked to reveal how he voted in the last election. He refuses to answer until the committee chairman informs him that he will be prosecuted for contempt if he does not cooperate. Under fear of prosecution he tells the committee that he voted for the Communist Party. His reply receives wide news coverage; his name is placed on the committee's black list and on the lists of other similar groups. His friends, business associates and employer learn of his political preferences, and the committee suggests that they take appropriate action.

Whether the committee's compelling Witness $A$ to answer has violated the First Amendment depends on two questions: has the committee's action abridged the political process?; and if so, does the abridgment meet the tests of the First Amendment?

\section{Abridgment of the Political Process}

In addition to its impact on Witness $A$, the committee's action has serious effect on the minds of the radio listeners and newspaper readers who learned of Witness $A$ 's experience. Many of them comprehend that if those aspects of their voting record which they do not wish publicized were spread across the headlines, they could be seriously embarrassed in their social and economic dealings. Although few voted for the Communists, many have cast a ballot for an unpopular candidate or party at some time in the past. People who never voted in ways that would embarrass them realize now that they must vote with an eye to the possibility of public examination by an investigating committee.

The result of the committee's action is to deter many of these people from lawful political activity in which they would otherwise have engaged. They know that they will run much less risk of exposé and embarrassment if they

nated against, Schenck v. United States, 249 U.S. 47, 52 (1919) (dictum). The ideas prohibited under the latter test may create a likelihood of various harmful audience reactions that the legislature could ban, e.g., Dennis v. United States, 341 U.S. 494 (1951) (attempts at revolution); Feiner v. New York, 340 U.S. 315 (1951) (riot) ; Giboney v. Empire Storage Co., 336 U.S. 490 (1949) (violation of antitrust law); Chaplinsky v. New Hampshire, 315 U.S. 568 (1942) (assault). 
confine their political activity to those orthodox means and goals which are least likely to attract committee attention and, which, if revealed, would cause the minimum public hostility. By compelling Witness $A$ to answer questions about his past voting, the committee has deterred other people from casting their ballots freely in the future, and has thus abridged the political process. ${ }^{100}$ The First Amendment is, therefore, brought into play; the committee's action must be tested against the twin criteria of least abridgment and nondiscrimination.

\section{The Least Abridgment Test}

To meet the standards of the First Amendment, a restriction must be justified by a substantial legislative purpose. Two objectives can be suggested for committee action of the sort under discussion:101 getting facts for legislation and informing the public about political behavior. ${ }^{102}$

100. In similar First Amendment cases where the argument has been made, the Court has examined the deterrent effect on other persons of abridgment of a particular defendant's activity. E.g., United States v. Harriss, 347 U.S. 612, 626 (1954) (as narrowly construed, the statute does not deter too many people); Wieman v. Updegraff, 344 U.S. 183, 191 (1952) (deterrence of observers is one reason statute is unconstitutional) ; Dennis v. United States, 341 U.S. 494, 501 (1951) (as narrowly construed the statute does not deter too many people); American Communications Ass'n v. Douds, 339 U.S. 382, 393, 402-05 (1.950) (nondiscriminatory, necessary restriction on affiliation of union officers as by-product of regulation of union is constitutional) ; Martin v. City of Struthers, 319 U.S. 141, 143 (1943) (restriction of speaker's freedom unconstitutionally restricts audience's right to hear) ; Thornhill v. Alabama, 310 U.S. 88, 97 (1940) (same); United States v. Rumely, 345 U.S. 41, 57 (1953) (concurring opinion) (deterrence of observers is unconstitutional); United States v. CIO, 335 U.S. 106, 153 (1948) (concurring opinion) (restriction on union newspaper publishing is unconstitutional restriction of right of readers to get information).

101. Federal investigating committees are limited in scope by the Necessary and Proper Clause of the Constitution and the concept of separation of powers. In Kilbourn v. Thompson, 103 U.S. 168 (1880), a Senate investigation into the affairs of a real estate pool that owed money to a bankrupt debtor of the United States was declared unconstitutional for failure to meet these requirements. No subsequent Supreme Court case has invalidated an investigation because its purpose was improper, but the Court has specifically approved only three purposes for investigations: legislation, McGrain v. Daugherty, 273 U.S. 135, 178 (1927) ; supervising the public domain, Sinclair v. United States, 279 U.S. 263, 294 (1.929) ; and determining the validity of elections of Congressmen, United States v. Norris, 300 U.S. 564,573 (1937). Lower courts have permitted investigation for other purposes as well, e.g., Barsky v. United States, 167 F.2d 241, 246 (D.C. Cir. 1948) (dictum) (preserve government, propose constitutional amendments) ; United States v. Josephson, 165 F.2d 82, 89-90 (2d Cir. 1947) (dictum) (appropriating funds; exposure of political beliefs) (semble).

102. A third possible reason for the committee's behavior might be to punish Witness $A$ for voting for Communists. Such a questionable purpose should not be imputed to the committee unless its resolution proclaimed it. See note 4 supra and accompanying text.

If Congress had set out to punish Witness $A$ in this manner the committee action would violate the least abridgment test. Punishing people for their past voting records could not be upheld as a "substantial" purpose that justified abridgment of political freedom. See note 76 supra and accompanying text. In addition efforts to punish in this manner would meet obstacles in the Fifth, Sixth and Eighth Amendments, the prohibition against 


\section{Fact-Finding}

Fact-finding for legislation is a substantial purpose, ${ }^{103}$ but since another method less violative of the political process could have accomplished the same purpose, the committee's method is unjustified. The information Witness $A$ had to give to the committee could have been secured without publicity, and without identifying the witness. If the question had been asked in secret session and the answer kept confidential by the committee, information would have been gathered equally well, without extra cost or inconvenience, and without deterring any readers or onlookers. Insofar as the committee had to publish its findings to other members of Congress this could have been done without identifying the witness whose political activities or preferences had been revealed. Without such identification there would be no private sanctions against individuals, and consequently less deterrence of observers, even though the inconvenience and embarrassment to the individual subpoenaed would remain.

\section{Informing the Public}

Another legislative object may be postulated - that of informing the electorate about young voters' political behavior. Whether this meets First Amendment criteria should be distinguished from a similar question-whether under the "necessary and proper" clause Congress may compel testimony on any topic for purposes other than that of legislation. Supreme Court dicta have suggested that legislative powers of testimonial compulsion are narrowly restricted and that they may not be exercised merely to inform the public. ${ }^{104}$ Yet there are distinguished proponents of the "informing function of Congress," 105 and if the Court were forced to pass directly upon the issue, it might hold that in some

ex post facto laws and bills of attainder, and would probably be bad as a legislative encroachment on the judicial function. See Bailey v. Richardson, 182 F.2d 46, $69-74$ (D.C. Cir. 1950) (dissent), aff'd by an evenly divided court, 341 U.S. 918 (1951). See also United States v. Lovett, 328 U.S. 303 (1946).

103. See United States v. Norris, 300 U.S. 564, 573 (1937) ; McGrain v. Daugherty, 273 U.S. 135, 174 (1927) ; Quinn v. United States, 349 U.S. 155, 160 (1955) (dictum).

104. The Supreme Court has never specifically approved the use of the legislative investigating power for the purpose of educating the electorate. See note 102 supra. In the Rumely case Justice Frankfurter appeared to recognize the validity of investigations for the purpose of performing the "informing function of Congress," United States v. Rumely, 345 U.S. 41,43 (1953), but it is not clear whether he meant informing the electorate or informing the Congress. See $i d$. at 46 . And he suggested that the validity of investigations for this purpose ended where the First Amendment's policy began. Id. at 44-46. See text at note 25 supra.

An official agency propagandizing the electorate on the subject of private politics poses obvious dangers to popular control of government, since its mere statements may have a coereive effect. Cf. Matter of Standard-Coosa-Thatcher, 85 N.L.R.B. 1358 (1949) (employer interrogation of employees about union affiliation is an unfair practice, interfering with self-organization, and is not an example of employer's protected free speech). See also United States v. Rumely, 345 U.S. 47, 57 (1953) (concurring opinion).

105. E.g., Wrlson, Congressional Government 297, 303 (1885); Carr, The House Comanitiee on Un-American Activities 1945-1950, at 7 (1952). 
circumstances the legislature can force witnesses to give information for that purpose alone.

Even if this goal is sufficient under the "necessary and proper" clause to justify testimonial compulsion generally, the additional question remains whether it is a "substantial" enough governmental purpose to justify questions about First Amendment subject matter. The process entails a balancing of interests and needs, but, as suggested in the Rumely and Quinn cases, the necessity of preserving political freedom might outweigh the benefits of additional public information.

A third factor dictating against the constitutionality of the question asked Witness $A$ is that less restrictive alternatives could accomplish substantially the same objective. Public interrogation of witnesses is undoubtedly helpful in drawing and keeping public attention. Nevertheless, by using imaginative radio and television techniques dramatizing the results of their inquiry, the committees could still get their messages across to the public without identifying the politics of individuals. A court might well find such alternative techniques feasible enough to condemn open-session interrogation as "unnecessary" for educating the voters.

\section{The Discrimination Test}

Even if it got by the least abridgment test, the action of the committee in the hypothetical example would be unconstitutional under the other aspect of the First Amendment-the ban on discrimination against individuals' political efforts on the basis of the programs they seek for government adoption. The Supreme Court has often invoked the discrimination test to strike down regulatory schemes that gave officials too much discretion to permit or deny the exercise of First Amendment rights. ${ }^{106}$ These regulatory plans showed no discriminatory purpose on their face, but were unconstitutional because they were too susceptible to discriminatory application. Even when there was no proof that the system had been abused to the harm of the particular litigant, the Court has invalidated a statute affecting him because of the likelihood that abuse would occur on another occasion. ${ }^{107}$

For the same reasons the resolution establishing the committee that questioned Witness $A$ is unconstitutional as unreasonably susceptible to discriminatory application. Under the resolution, the committee is given almost unfettered discretion in selecting witnesses and the questions to be asked them. Such discrimination has already marked the history of legislative investigations: vague authorizing resolutions ${ }^{108}$ have allowed the members of a com-

106. E.g., Niemotko v. Maryland, 340 U.S. 268, 272 (1951); Saia v. New York, 334 U.S. 558, 560-61 (1948); Thornhill v. Alabama, 310 U.S. 88, 97 (1940) ; Schneider v. State, 308 U.S. 147, 164 (1939).

107. Kunz v. New York, 340 U.S. 290 (1951); Saia v. New York, 334 U.S. 558 (1948).

108. E.g., The House Un-American Activities Committee "is authorized to make from time to time investigations of (i) the extent, character, and objects of un-American propa- 
mittee or its staff to select individuals of one political stripe for public humiliation while ignoring individuals of other persuasions who were otherwise equally eligible for investigation. ${ }^{109}$

But the Court would not need to measure the likelihood of committee abuses in order to strike down on its face a resolution which authorized publicized compulsory interrogation about politics; even if a committee did not discriminate in choosing the targets of investigation discrimination would inevitably result from popular reactions. Witnesses who are forced to reveal unorthodox political ties meet more hostility than those who reluctantly reveal themselves to be Republicans or Democrats. As long as committees investigate and publish the political preferences of identified individuals the result will be pressure on citizens to drop unorthodox programs in favor of more conventional ones. The conclusion must follow that any resolution authorizing public investigation of political matters is so likely to have this improper discriminatory effect that it violates the First Amendment on its face.

To state the rule of Witness $A$ 's case more generally, both aspects of the First Amendment are violated whenever an investigating committee compels a witness to give publicized testimony about private political activities. It remains to be seen how the courts can draw this constitutional line, and how large an area it should circumscribe.

\section{Problemis of Application and Scope The Limits of Judicial Protection}

Although there would be a First Amendment abridgment on any occasion when a committee focused hostile public opinion on an individual's political activity, the judiciary would not always be able to give protection or redress. ${ }^{110}$ In practice, the question would only come before the courts in a contempt prosecution brought against a witness who refused to testify. ${ }^{111}$ In such a case, if

ganda activities in the United States ...."; the word "un-American" is nowhere defined. Act of Aug. 2, 1946, c. 753, $\$ 121$ (b) (1) (8) (2), 60 Srat. 828. The Senate has recently authorized a special committee "to investigate the subject of attempts to influence improperly or illegally the Senate or any member thereof, or any candidate therefor, or any officer or employee of the Government, through campaign contributions, political activities, lobbying, or any and all other activities and practices." 102 CoNG. Rec. 2702-03 (daily ed. Feb. 25, 1956). And see Barrett, The Tenney CoMmittee 15-16 (1951) (quoting authorizing resolution).

109. See Chamberlain, A Generation of Legislative Alarm, in The States and SubVERsion 243-45 (Gellhorn ed. 1952) ; Harsha, The Broyles Commission, in id. at 66-75; CARR, ap. cit. supra note 105, at 280-84 (1952) ; cf. United States v. Josephson, 165 F.2d 82, 92 (2d Cir. 1947) (holding discrimination in choice of subjects of investigation not unconstitutional).

110. The Supreme Court cannot act unless there is a "case" or "controversy." U.S. Const. art. III, \$2. United Public Workers v. Mitchell, 330 U.S. 75 (1946) ; Federation of Labor v. McAdory, 325 U.S. 450 (1945).

111. Most cases involving the constitutional limits of the investigating power have been federal prosecutions against witnesses under 11 STAT. 155 (1857), as amended, 2 
the witness had invoked the First Amendment as grounds for refusal to testify, the trial court should acquit him.

Although this would be effective in freeing witnesses from the necessity of answering certain questions, it would by no means cover every instance of abridgment by a committee. At least three recurrent situations would probably remain largely beyond the reach of the courts, for procedural reasons $:^{112}$ where

U.S.C. $\$ 192$ (1952), which makes it a federal crime to wilfully refuse to testify or wilfully refuse to produce documents before a congressional committee. Under these statutes a witness who refuses to testify is prosecuted by a United States attorney when the committee he offended reports the facts to its parent chamber and the President or Speaker of the chamber certifies them to the United States attorney. 11 Stax. 156 (1857), as amended, 2 U.S.C. $\$ 194$ (1952).

On occasion both houses of Congress have punished contumacious witnesses without resort to the courts, exercising their common law powers as legislative chambers. E.g., Jurney v. MacCracken, 294 U.S. 125 (1935) ; McGrain v. Daugherty, 273 U.S. 135 (1927); Stewart v. Blaine, 8 D.C. (1 MacArth.) 453 (1874). In these cases judicial review was obtained by the witness' action for false arrest brought against the Sergeant-At-Arms or Speaker who caused his arrest, or else by a petition for a writ of habeas corpus. But the common law procedure is rarely used. See In re Chapman, 166 U.S. 661, 671 (1897).

In one recent case a witness was indicted under 18 U.S.C. $\$ 1505$ (1952) for wilfully obstructing a congressional committee, but the count was dismissed by the district court. United States v. Starkovich, 1. Crv. LrB. Dock. § 340.4 (W.D. Wash. 1955).

Enforcement proceedings in cases involving state committees are similar. E.g., In rc Battelle, 207 Cal. 227, 277 P. 725 (1929) (common law punishment for contempt); People ex rel. McDonald v. Keeler, 99 N.Y. 463, 2 N.E. 615 (1885) (same); Ohio v. Morgan, 164 Ohio St. 529, 133 N.E.2d 104 (1956) (criminal prosecution). But in some states investigating procedure provides for obtaining a court order compelling a witness to answer, and only the witness' subsequent recalcitrance is contempt. E.g., Attorney General v. Brissenden, 271 Mass. 172, 171 N.E. 82 (1930) ; Matter of Barnes, 204 N.Y. 108, 97 N.E. 508 (1912); cf. Nelson v. Wyman, 99 N.H. 33, 105 A.2d 756 (1954). A similar procedure for federal investigations has been suggested, TAYLoR, GRAND Inguest 261. (1955), but is not yet available, $c f$. Mins v. McCarthy, 209 F.2d 307 (D.C. Cir. 1953).

The First Amendment issue may also arise in a prosecution of a witness for allegedly giving perjured testimony to a committee. See United States v. Lattimore, 215 F.2d 847, 851 (D.C. Cir. 1954). However, in perjury prosecutions the Court might hold that the witness has waived his First Amendment objection to committee questions by answering them. See note 118 infra.

112. If the government brings no action and the investigated individual attempts to sue as plaintiff for redress he will either ask for money damages or injunction and declaratory judgment. In the money damage suit he will be met with objections of: legislators' immunity for their official speech, e.g., Kilbourne v. Thompson, 103 U.S. 168 (1880); sovereign immunity, e.g., 28 U.S.C. \& $2680(\mathrm{~h})$ (1952) (Federal Tort Claims Act does not waive governmental immunity for defamation); the immunity of high government officers in the scope of their authority, e.g., Gregoire v. Biddle, 177 F.2d 579 (1949), cert. denied, 339 U.S. 949 (1950); United States being a necessary party to suits against officials, e.g., Larson v. Domestic \& Foreign Commerce Corp., 337 U.S. 682 (1948).

If he sues for an injunction and/or declaratory judgment he will also meet obstacles: his standing to sue, e.g., United Public Workers v. Mitchell, 330 U.S. 75 (1947), but see Adler v. Bcard of Education, 342 U.S. 485 (1952); separation of powers, e.g., Fischler v. McCarthy, 117 F. Supp. 643 (S.D.N.Y.), aff'd on other groumds, 218 F.2d 164 (1954) ; 
a witness gives testimony in secret session which is later published $;^{113}$ where a witness who refuses to answer a question is publicly called a "First Amendment Communist" or similar epithet, but is not prosecuted for contempt;114 and where a person is not himself called to the stand but is identified and has his political beliefs or activities discussed by other witnesses. ${ }^{115} \mathrm{~A}$ judicial solution to the first two problems is unlikely. ${ }^{116}$ In the third situation the courts cannot prevent public denunciations by "friendly" witnesses, but they can protect those "unfriendly" witnesses who invoke the protection of the First Amendment.

Deterrence of onlookers-the crux of the abridgment here-follows as surely when a witness is asked about someone else's activities as when he is questioned about his own. If the other person is identified and subjected to hostile publicity the deterrent effect on the onlooker is no less than if the witness himself were singled out. But there is virtually no way such a third person iden-

cf. Mins v. McCarthy, 209 F.2d 307 (D.C. Cir. 1953) ; political question, e.g., Colegrove v. Green, 328 U.S. 549 (1946); exhaustion of remedies, e.g., Aircraft \& Diesel Corp. v. Hirsch, 331 U.S. 752 (1947); equity discretion to decline jurisdiction, e.g., Railroad Comm'n v. Pullman Co., 312 U.S. 496 (1941). Research has produced only five cases in which a person sought relief against federal legislative investigation before the government brought contempt proceedings against him, and in all five cases the attempt at judicial relief failed: Mins v. McCarthy, supra (semble: separation of powers); Hearst v. Black, 87 F.2d 68 (D.C. Cir. 1936) (same); Methodist Federation for Social Action v. Eastland, Civil No. 1845-56, D.D.C., May 25, 1956 (same; congressional privilege) ; Fischler v. McCarthy, supra (venue, no federal jurisdictional amount, ripeness, separation of powers); Hutner v. McCarthy, Civil No. 89-364, S.D.N.Y., Dec. 8, 1953 (no written opinion); cf. Tenney v. Brandhove, 341 U.S. 367,378 (1951).

Different results may obtain in state courts since state investigating procedure is often different from federal; state courts are not restricted to hearing only "cases and controversies," and their doctrines of standing to sue are often less rigid. Compare Greenfield v. Russel, 292 I11. 392, 127 N.E. 102 (1920) (taxpayer allowed to enjoin State Treasurer from paying out public funds to an unconstitutional investigating committee), with Massachusetts v. Mellon, 262 U.S. 447 (1923) (federal taxpayer has no standing to sue to enjoin payment of public funds) ; and compare Nelson v. Wyman, 99 N.H. 33, 105 A.2d 756 (1954) (witness subpoenaed by state investigators may get declaratory judgment as to permissible scope and manner of testifying), with, e.g., Fischler v. McCarthy, supra (refusing similar relief to witness subpoenaed by federal investigators).

113. Concerning this practice see authorities cited in note 14 supra. In a state case now pending a private citizen is attempting to enjoin publication by an investigating committee of a list of subversives. Tormey v. Bowker, 1 CIv. LIB. Dock. $\$ 170.3$ (Mass. Sup. Jud. Ct. 1956). In an earlier case in the same state the plaintiff lost for lack of standing to sue. Kaplan v. Bowker, 1 Civ. Lis. Dock. $\$ 170.2$ (Mass. Sup. Jud. Ct. 1955).

114. On the practice of committees insulting uncooperative witnesses, see CARR, $o p$. cit. supra note 105, at 216; TAYLOR, GRAND INQUEST 3, 184-85 (1955) ; Government Printing Office Hearings 64; cf. TAYLOR, op. cit. supra at 117-20.

115. See CARR, op. cit. supra note 105, at 181-82, 315-19. Many proposed codes of procedure for committees have been directed to this problem. See, generally, EmIERSon \& HABER, op. cit. supra note 84 , at $456-58$.

116. See text at note 134 infra. 
tified by the witness can raise the question in the courts. ${ }^{117}$ Such protection as the judiciary can throw around him must be invoked by the witness who is on the stand, or not at all. If the witness is a "cooperative" one, he may ignore the First Amendment privilege, and discuss the political affairs of other persons, ${ }^{118}$ and there is probably nothing the courts can do about it. But if the witness is unwilling to testify about the activities of others, he should be able to refuse to do so on First Amendment grounds without fear of a contempt conviction, even if his own activities are not the subject of inquiry. ${ }^{119}$

At first glance such a witness would seem to be trying to enforce the rights of third persons, which he cannot do unless he runs the maze of cases involv-

117. To get redress the third person must bring suit as a civil plaintiff, encountering all the obstacles mentioned in note 112 supra. As is pointed out in the note cited, the problem may not be so grave in the state courts as in the federal.

118. Whether a witness before an investigating committee can waive, and what constitutes waiver of the First Amendment privilege for himself and third persons, have not been discussed by the courts. In contempt prosecutions under 2 U.S.C. $\$ 192$ (1952), a witness may raise the defense that the question he refused to answer was not pertinent although he did not make the same claim at the time he was asked the question by the investigating committee. Bowers v. United States, 202 F.2d 447 (D.C. Cir. 1953). But in such prosecutions the self-incrimination privilege is waived unless claimed properly before the committee. Quinn v. United States, 349 U.S. 155, 164-65 (1955) (dictum). In United States v. Lattimore, 215 F.2d 847, 851 (D.C. Cir. 1954), the court assumed that a witness did not waive his First Amendment privilege by testifying freely to an investigating committee, but found that the questions asked him were not privileged.

The closest Supreme Court case is Ullmann v. United States, 24 U.S.L. WEEK 4147, 4152 n.15 (U.S. Mar. 26, 1956), where the Court upheld the conviction of a grand jury witness who had refused to answer questions about his own and other persons' membership in the Communist Party. The Court treated the First Amendment defense of the witness as waived. The precise time at which the waiver occurred is not, however, made clear. Compare United States v. Bryan, 339 U.S. 323, 330-33 (1950) (defense that committee had no quorum treated as waived since witness' refusal to give records to committee was not in fact based on that defense).

119. The suggested application of the First Amendment would create a privileged topic about which committees could not compel testimony for unrestricted publication. The mechanics of the privilege would be similar to the privilege for trade secrets now recognized in civil litigation. See, generally, 8 WIGMORE, EvIDENCE $\$ 2212$ (3d ed. 1940). The policy of the proposed privilege would be closer to the existing privilege for political votes: "to secure the entire independence of the electors, to enable them to vote according to their own individual convictions of right and duty, without the fear of giving offense or exciting the hostility of others." $8 i d . \$ 2214$.

Wigmore has argued against enlarging the testimonial privilege to cover political opinion, ibid., and his result is compatible with the suggested application of the First Amendment. Since the least abridgment test only bars unnecessary abridgments, public testimony about politics may be compelled in court where it is stuject to strict rules of relevancy and where there is no other way in which the triers of fact can get the information in a public trial. However, the privilege should obtain in public committee examinations of witnesses where the rules of pertinency provide very little control and publicity is not necessary to ensure a fair "trial." Of course there should be no privilege if there is no danger of publicity. See text at notes 134-35 infra. 
ing the "standing" of a litigant to sue to enforce the rights of others ;20 but on closer analysis this problem dissolves. The "standing to sue" issue arises only when a plaintiff attempts to assert the rights of third persons ; ${ }^{121}$ where, as in the case of the witness prosecuted for contempt, the interests of third persons are invoked by a defendant the real question is that of his substantive defenses ${ }^{122}$-and unconstitutionality of a question asked is clearly a defense to a prosecution for refusing to answer it. ${ }^{123}$ The remaining issue is the proper way of testing the unconstitutionality of the question: is it bad if it abridges any part of the political process, or is it bad only if it abridges the defendant's own political freedom? If the previous analysis was correct, the amendment is concerned with deterrence of any part of the political process. Compulsory public questioning is unconstitutional if it unnecessarily abridges anyone's political activity or discriminates between candidates or government programs. It is immaterial whether the unnecessary or discriminatory questions concern the witness or another person. The effect on observers is the same in either event. $^{124}$ Since a question about other people's politics is unconstitutional, the witness should be allowed to plead this in his own defense when prosecuted for contempt. ${ }^{125}$ This is especially true in the context of legislative investi-

120. See Joint Anti-Fascist Refugee Comm. v. McGrath, 341 U.S. 123, 150-56 (1951) (concurring opinion). See, generally, Hart \& Wechsler, The Federal Courts and the Federal Systear 156-92 (1953).

121. See, generally, id. at $156-75$.

122. The term "defendant's standing" has been used to describe the issue of whether the defendant will be allowed to challenge a statute "on its face"-i.e., as it may be applied in other instances than his own. See id. at 176-92. A witness cited for contempt would not have to challenge the committee's resolution on its face to invoke the least abridgment test even if the question he refused to answer concerned the activities of another person. In that instance his challenge would be not to the application of the resolution on other hypothetical occasions, but to the specific question asked him.

To raise the First Amendment's nondiscrimination test as a defense in a contempt prosecution, the defendant would either have to prove discrimination occurred in his case or else challenge the resolution on its face. Such a challenge was permitted in United States v. Josephson, 165 F.2d 82, 90 (2d Cir. 1947), and denied in Barsky v. United States, 167 F.2d 241, 248 (D.C. Cir. 1948) (semble).

123. United States v. Rumely, 345 U.S. 41 (1953) ; Bowers v. United States, 202 F.2d 447 (D.C. Cir. 1953). Constitutionally privileged answers may be withheld without incurring criminal liability. E.g., Quinn v. United States, 349 U.S. 155 (1955) (self-incrimination). Compare Poulos v. New Hampshire, 345 U.S. 395 (1953) (unconstitutional application of a valid law may not be raised as a defense in enforcement proceedings where government has provided regular channel for judicial review of application of law).

124. See text at pp. 1179-80, and note 100 supra; cf. Barsky v. United States, 167 F.2d 241, 246 (D.C. Cir. 1948) :

"We note at this point that the arguments directed to the invalidity of this inquiry under the First Amendment would apply to an inquiry directed to another person as well as one directed to the individual himself."

125. If the First Amendment creates a testimonial privilege as described in note 118 supra, the defendant in contempt proceedings should be able to plead as a defense that the answer was privileged and the fact that the privilege was for the protection of another 
gations, where the third person, whose activities the question concerns, is unable to defend his own rights because of procedural obstacles. ${ }^{126}$

When, as in this context, an individual has attempted to justify nonperformance of a legal duty on the ground that performance would involve violating the constitutional rights of third persons, the Court has permitted the defense. ${ }^{127}$ However, where a party tries to justify nonperformance of a statutory obligation on the ground that the statute, although constitutional as applied in the present instance, would be unconstitutional if applied in another hypothetical case the Court has generally rejected the argument. ${ }^{128}$ In a few First Amendment cases the rule has been relaxed and such a challenge to a statute "on its face" has been permitted. ${ }^{129}$

The judicial application of the First Amendment to committees depends, then, upon the witness. He can, in an appropriate case, invoke the amendment as grounds for refusing to answer, and if the committee has him cited for contempt, his claim should be upheld by the courts. The appropriate case for such invocation of the amendment has been indicated only in prototype ; a more comprehensive definition of the circumstances in which the First Amendment applies is necessary. This definition must provide a guide to the degree of publicity that condemns a congressional inquiry, and a way of distinguishing between questions that may be asked and those that may not.

person and not himself should not matter. Cf. Blau v. United States, 340 U.S. 332 (1951) (husband not guilty of contempt for refusing to disclose privileged communication from his wife).

126. See Joint Anti-Fascist Refugee Comm. v. McGrath, 341 U.S. 123, 187 (1951) (concurring opinion). It may be that if no one has an opportunity in any forum at any time to challenge the constitutionality of the question asked the witness about a third person, enforcement proceedings against the witness in a federal court will violate article III of the Constitution, or the Due Process Clause. See Hart \& Wecrisler, op. cit. supra note 120 , at $312-40$.

127. Barrows v. Jackson, 346 U.S. 249 (1953) ; Martin v. City of Struthers, 319 U.S. 141, 143 (1943); Thornhill v. Alabama, 310 U.S. 88, 97 (1940). When a person who would normally be the defendant in a government action to enforce a statute brings a declaratory judgment or injunction suit to determine whether it is constitutional, the Court has permitted him to raise the question of whether the statute requires him to take action which would impair the constitutional rights of third persons. E.g., American Communications Ass'n v. Douds, 339 U.S. 382, 393, 402-05 (1950) ; Board of Education v. Barnette, 319 U.S. 624, 630 (1943) (parent can test validity of law punishing him for failure to send his children to a school, where they will be compelled to salute the flag in violation of their religious beliefs).

128. E.g., Jeffrey Mfg. Co. v. Blagg, 235 U.S. 571 (1915); Yazoo \& Miss. Valley R.R. v. Jackson Vinegar Co., 226 U.S. 217 (1912) ; Southern Ry. v. King, 217 U.S. 524 (1910). Where the statute in question was federal, the Court has sometimes allowed the argument. E.g., The Employers' Liability Cases, 207 U.S. 463, 500-02 (1908) ; The TradeMark Cases, 100 U.S. 82, 98-99 (1880) ; United States v. Reese, 92 U.S. 214 (1876). But see Electric Bond \& Share Co. v. SEC, 303 U.S. 419 (1938) ; The Abby Dodge, 223 U.S. 166 (1912).

129. E.g., Kunz v. New York, 340 U.S. 290 (1951) ; Saia v. New York, 334 U.S. 558 (1948) ; Thornhill v. Alabama, 310 U.S. 88 (1940). But see, e.g., Cox v. New Hampshire, 312 U.S. 569 (1941). 


\section{Publication}

Unless the testimony is published in a way that may cause people to discriminate against the persons investigated because of their politics, neither the witness nor others are deterred from exercising political rights. Commonly witnesses are interrogated by legislative committees in open session, with the press and perhaps television and radio present, so that broad publication is simultaneous with the witness' disclosure. In such circumstances, if the question concerns forbidden topics, the witness should be able to refuse to answer it because the likelihood of publication and deterrence of observers is so great.

More difficulty arises if the witness is questioned in private-in executive session-where there is no immediate likelihood of publication. Whether or not the content of the testimony will be released in a way that will cause popular hostility against the people under investigation depends upon future acts of the committee. In the past, committees have refused to give witnesses a pledge of secrecy, ${ }^{130}$ and have revealed a great deal of what they gleaned in private session. ${ }^{131}$ Facts obtained in executive session have later been released in press conferences, reports to the legislature, and pamphlets published by the committees, and have been dispensed from committee files for the convenience of employers desiring to discriminate against the blacklisted people. ${ }^{132}$ Many committees seem to have considered it their duty to inform the voters of the identity of individuals with undesirable political tendencies, so that these people might be more easily recognized and ostracized in the future. ${ }^{133}$ Even when the committees have not made deliberate efforts to identify the politics of specific people, the information has often "leaked" to the press. ${ }^{134}$

In the light of this history and of the dilemma of the witness who himself is unable to predict the committee's course of conduct, the courts should presume that all compulsory testimony given an investigating committee will eventually be published unless special circumstances are shown that make publication very unlikely. One circumstance overcoming the presumption of publication would be a committee promise to prevent publication of the testimony in a manner that would allow anyone to identify the person whose political activities the testimony was about. Where such a pledge was extended the courts and the witness should assume it would be honored, and the witness

130. See United States v. Orman, 207 F.2d 148 (3d Cir. 1953) (witness who refused to produce subpoenaed business records because Kefauver Committee would not pledge secrecy for their contents held guilty of contempt).

131. See note 14 supra; CARR, op. cit. supra note 105 , at 153-65; cf. N.Y. Times, Feb. 28, 1956, p. 1, col. 2 (House Un-American Activities Committee releases information on Manhattan Borough President) ; Mar. 27, 1956, p. 23, col. 1 (Senate Subcommittee on Internal Security publishes the private papers of Harry Dexter White).

132. E.g., N.Y. Times, Aug. 16, 1955, p. 1, col. 1; CARR, op. cit. supra note 105, at 153-65; TAYLOR, GRANd InQUeST 244-47 (1955).

133. See note 19 supra.

134. See CARR, op. cit. supra note 105, at 153-65; TAyloR, Grand Inquest 244-47 (1955). 
should be held in contempt if he still refused to testify. Neither witness nor court could very well presume that the legislators would fail to keep confidence once they had agreed to do so. ${ }^{135}$

\section{What Questions May Not be Asked}

In general, any question should be permitted unless its answer would be likely to deter lawful private political activity or belief. A witness prosecuted for contempt cannot, of course, produce direct proof that deterrence would have resulted had he answered; he should only be required to show that the answer he refused to give was likely to deter protected behavior if published. Whether or not a given answer was of this character would depend on a host of factors, a few of which require attention here because they might be thought to establish conclusively that a particular answer would or would not have the effect of abridgment. Some of these critical variables concern the identity of the person investigated; others concern the type of behavior under investigation.

\section{Identity of the Person Investigated}

Aliens, government employees and fictional persons often do not enjoy the full range of political rights enjoyed by ordinary citizens, ${ }^{136}$ and for this reason it might be suggested that these three groups could be subjected to unlimited investigation without serious impairment to lawful political activity. But these persons play a significant part in the political process despite limitations on their activities. ${ }^{137}$ Unrestricted investigation, even if it only deterred them from exercising their limited rights, would still be sufficiently substantial abridgment

135. In case of a legislative breach of secrecy there would be no redress in court, but legislatures can enforce their own rules of secrecy. See Ex parte Nugent, 18 Fed. Cas. 471, No. 10375 (C.C.D.C. 1848).

136. E.g., Harisiades v. Shaughnessy, 342 U.S. 580,586 nn.9 \& 10 (1952) (aliens); United Public Workers v. Mitchell, 330 U.S. 75 (1947) (government employees); cf. United State's v. CIO, 335 U.S. 106 (1948) (fictional persons). See, generally, Comment, The Expatriation Act of 1954, 64 Y ALE L.J. 1164, 1166-69 (1955) (aliens); Chang, Labor Political Action and the Taft-Hartley Act, 33 Neb. L. Rev. 554, 561 n.37 (unions); Earerson \& Haber, Political \& Civil Rights in the Unimed States 344-46 (1952) (government employees).

137. On the part unions play in the political process despite laws restricting their campaign contributions, see Chang, supra note 136; Hudson \& Rosen, Union Political Action: the Member Speaks, 7 IND. \& LAB. REL. Rev. 404 (1954). On the current role of corporations see Key, Politics, Parties and Pressure Groups 55455 (3d ed. 1952). Government employees are not prevented from voting and expressing political opinions, even if they are prevented from more active campaigning by the Hatch Act. United Public Workers v. Mitchell, 330 U.S. 75, 94 (1946). But their freedom to express left-wing opinions may have been curtailed by the federal loyalty program. See Emerson and Helfeld, Loyalty Among Government Employees, 58 Yare L.J. 1, $76-79$ (1948). Aliens, like fictional persons, are denied the franchise in all forty-eight states. Book of the STATEs 1955-56, at 84-85. But they are permitted to express their political opinions, contribute to campaign funds, and help organize political groups. 
to call the First Amendment into play. ${ }^{138}$ Moreover, the deterrence produced by investigating any of these groups would not be confined to members of the group unless ordinary citizens observing the inquiry felt sure that there was no likelihood of similar investigations of themselves.

\section{The Kind of Conduct Investigated}

Since the First Amendment only protects lawful political activity or belief, an argument might be made that questions about nonpolitical activity or about political activity which is illegal cannot violate the policy of the amendment. Generally, questions about nonpolitical behavior will not deter observers from freely exercising their political rights and consequently such queries raise no First Amendment issues. ${ }^{139}$

But questions about illegal political action (such as bribery, sedition or unregistered lobbying), require special consideration since compulsory public interrogation about these matters is likely to cause observers to refrain from lawful as well as unlawful efforts to influence the government. For example, membership in the Communist Party may be illegal under the Smith Act, ${ }^{140}$ and consequently unprotected by the First Amendment. But the glare of unfavorably publicity thrown on Party members by legislative committees may

138. The argument for free investigation of these groups would rest on the assumption that existing restrictions on them have been held constitutional because the groups lack First Amendment protection afforded other persons. But these groups are protected by the First Amendment, and curtailment of their political action must meet the same constitutional tests as curtailment of other persons' activities. Wieman v. Updegraff, 344 U.S. 183 (1952) (government employee) ; Bridges v. California, 314 U.S. 252 (1941) (alien, corporation); Grosjean v. American Press Co., 297 U.S. 233 (1936) (corporation); cf. Kwong Hai Chew v. Colding, 344 U.S. 590, 596 n.5 (1953) (dictum) (alien); United States v. CIO, 335 U.S. 106, 154-55 (1948) (concurring opinion) (unions and corporations).

Of course, under the least abridgment test, see text at notes 76-78 supra, what is "necessary" in the case of these people may not be "necessary" in the case of ordinary citizens if the occasion for legislative action is a problem peculiar to these classes of people. $C f$. Adler v. Board of Education, 342 U.S. 485 (1952) (fitness for government employment) ; Harisiades v. Shaughnessy, 342 U.S. 580, 591-92 (1952) (deportation of undesirable alien); United Public Workers v. Mitchell, 330 U.S. 75 (1947) (spoils system). Garner v. Board of Public Works, 341 U.S. 716 (1951), appeared to ignore the least abridgment test in cases of government employees, but subsequent cases have restored it. Wieman v. Updegraff, supra (discharge for innocent membership in groups advocating force or violence is unconstitutional); Adler v. Board of Education, supra at $492-93$ (discharge of teacher for membership in a group advocating force and violence is constitutional because this is only practical way to ferret out subversive propaganda in schools).

139. Questions may, of course, raise serious problems under other parts of the Constitution. See, Emspak v. United States, 349 U.S. 190 (1955) (self-incrimination); $c f$. Barsky v. United States, 167 F.2d 241, 262-63 (D.C. Cir. 1948) (dissenting opinion) (due process).

140. 18 U.S.C. $\$ 2385$ (1952). See United States v. Lightfoot, 228 F.2d 861 (7th Cir. 1955), cert. granted, 24 U.S.L. WeEK 3252 (U.S. Mar. 26, 1956) ; Scales v. United State's, 227 F.2d 581 (4th Cir. 1955). 
well keep observers from joining other groups not in themselves unlawful and only similar to the Party in that they are also in the shadow of community disapproval. In the case of criminal prosecutions under the Smith Act this "penumbra of deterrence" is unavoidable, for trials must be public. But there is no similar necessity justifying public legislative investigation of political crime.

A practical difficulty would obstruct any effort to allow public questions about political crimes while forbidding public probing of lawful political activity. In order to make an intelligent investigation a committee would inevitably have to ask questions about lawful politics as a background to its questions about crime. It would frequently be impossible to tell whether the question which a witness refused to give was one concerning legal or illegal political effort; even the relatively specific crime of bribery rapidly shades off into the nuances of lawful contributions to campaign funds.

A possible exception to the rule barring public investigation of politics might be urged for inquiries into "direct lobbying." In the Harriss case ${ }^{141}$ the Court sustained a federal law requiring professional lobbyists to register and publish information about their finances, their activities and the identity of their employers. ${ }^{142}$ In order to avoid First Amendment difficulties the Court construed the statute to apply only to persons involved in "direct" lobbying, entailing face-to-face contact with legislators, and not to those whose lobbying was "indirect." ${ }^{143}$ The Court recognized that such registration and publication had a deterrent effect on legitimate political activity, ${ }^{144}$ but found that it was justified, as to "direct lobbying," by the fact that Congress needed information about professional groups in order to gauge properly the extent to which they represented public opinion. ${ }^{145}$

The fact that the Court held a law requiring disclosures by professional direct lobbyists constitutional does not imply that public legislative investigation of direct lobbying would also be constitutional. The Court in Harriss pointed out that the statute was no broader than necessary to accomplish its purpose. $^{146}$ The information required by the statute was narrowly restricted, ${ }^{147}$ and publication-printed reports in the Congressional Record ${ }^{148}$-was hardly flamboyant. Furthermore, there could be no discrimination in the selection of persons about whom the publication was made, since all direct lobbyists were required to answer the same questions. ${ }^{149}$ The slight deterrence of lawful political activity caused by the statute was, therefore, justified under First

141. United States v. Harriss, 347 U.S. 612 (1954).

142. Federal Regulation of Lobbying Act, 60 Stat. 839 (1946), 2 U.S.C. $\$ \S 261-70$ (1952).

143. 347 U.S. at $617-26$.

144. Id. at 625-26.

145. Ibid.

146. Id. at 626 .

147. Id. at 625 .

148. Federal Regulation of Lobbying Act, 60 STAT. $841-42$ (1946), 2 U.S.C. $\$ 267$ (1952).

149. Id., 60 StAT. 840,841 (1946), 2 U.S.C. $\$ \S 262,266-67$ (1952). 
Amendment criteria. ${ }^{150}$ But in the case of legislative investigations of direct lobbying, carried on with the usual attendant publicity, a different situation would be presented. The variety of information publicized and the extent of publication would be considerably broader, and the deterrence correspondingly greater. And committee investigations would present an element of discrimination, ${ }^{151}$ which was carefully avoided in the statute held constitutional in the Harriss decision. The conclusion should be that direct lobbying, like any other part of the political process, is protected by the First Amendment against publicized investigation by the committees of Congress.

\section{A Formula for Application by the Courts}

As a practical matter the courts will have to use presumptions in deciding what questions a committee may properly ask. It has already been pointed out that since the constitutionality of a question depends upon the extent to which it deters lawful participation in the political process, and since this is not susceptible of direct proof, the courts will have to infer the likelihood of deterrence from a given question. The question remains whether inference should be carried a step further, to establish broad categories of questions and circumstances in which deterrence would be presumed without further inquiry. It is submitted that the courts should take just this course, establishing a per se rule for determining when a question violates the First Amendment. Certain categories of questions should be declared unconstitutional without requiring proof of the actual likelihood of their causing deterrence in a specific instance. The alternative would be to make an ad hoc determination of the likelihood of deterrence in each instance, taking into consideration all the variables that determine the probable effect of a committee's question. ${ }^{152}$ The loss from using a per se rule would be slight. In some situations the rule might protect too much, cutting out questions that in their context would not have actually abridged political freedom. But in those instances a committee would not be kept from asking the questions; it would only be required to ask them without publicity. Occasionally the rule might protect too little, but some liberality in drawing its dimensions could cure this defect. On the other hand, the disadvantages of leaving the issue to ad hoc determination would be considerable.

There is, first of all, a real need for certainty in this area. A witness on the

150. 347 U.S. at 625,626 .

151. A committee investigation of lobbying, unless it were to call lobbyists by lot or call all lobbyists for investigation, would have to exercise discretion in selecting which lobbies to examine and which to ignore. The results of such selection are indicated in text following note 109 supra.

152. Deterrence would vary with the type of political behavior revealed; the personality, social status and reputation of the person exposed; the amount and type of publicity given the exposé; the composition of the audience to which the person was exposed; the audience's opportunity to impose sanctions on the person; the extent to which persons in the audience feared similar sanctions against themselves; the number of persons who feared them; how strongly motivated they were to overcome their fear. 
stand needs to know whether he can safely invoke the First Amendment as grounds for refusing to answer a question: if he refuses to answer and later finds he guessed wrong, he may be convicted of contempt; ${ }^{153}$ if he answers and later learns that he need not have, there is no redress for him or for others whose rights have been abridged. He must decide quickly and correctly, and a vague rule may be worse than no rule at all. Predictability is equally important for the committee counsel trying to keep his questions within constitutional bounds : he must know when he is entitled to force a witness to speak up, and when he should conduct his questioning in executive session. Finally, some certainty about the rules is appropriate for other congressmen and citizens trying to evaluate the fairness of the committees' performance. ${ }^{154}$ An $a d$ hoc rule would provide almost none of this necessary certainty.

$A d$ hoc adjudication would leave the delineation of the law largely to the district courts, since the crux of each decision would be "findings of fact" and the scope of appellate review would be limited. Such piecemeal development by inferior courts would not encourage legislative self-restraint. Moreover, a proper regard for the delicate question of the separation of legislative and judicial powers should lead the Supreme Court to draw the line between proper and improper questioning itself, rather than delegating this task to the trial judges.

The general rule should be that witnesses have the right to refuse to reply to any question whose answer would describe the private political activities or beliefs of any person-unless there are adequate guarantees that the answer will not be published in a way that identifies the person. No exception should be made for any category of persons or activities or for any category of political activity or belief-legal or illegal. The test of what is "political" should be whether the belief or the activity was intended to influence government policy or the choice of government personnel. For those questions where the difference between political and nonpolitical subjects was blurred, some unpredictability would remain. But the uncertainty would center on a single issue about which a body of case law could easily be built; under an ad hoc rule, where a number of variables are always considered, past cases would be of little help in predicting future decisions.

In most cases scrutiny of the question asked a witness would indicate whether the political process was involved, but even such a seemingly nonpolitical question as "Where did you last see Harry Smith?" might require an answer about political activity. In such a case a witness who invoked the First Amendment should be allowed to prove in defense to a contempt prosecution that he could not in good faith have answered the question without discussing private political beliefs or actions. Whether or not the investigation was primarily focused

153. In some states a committee witness need not face this dilemma; investigating committees must get a court order to compel a recalcitrant witness to testify. In the proceeding for such an order the witness can get judicial review of the propriety of questions asked him without risking a contempt conviction. See note 111 supra.

154. See Editorial, N.Y. Times, Aug. 18, 1955, p. 22, col. 1. 
on political matters, the legality of a particular committee question should turn on the nature of the answer it requires.

\section{Effect of the Rule Proposed}

If the rule here suggested were adopted by the Court, its immediate effect would be to stop contempt convictions of committee witnesses who refused to answer questions about their own or other persons' political activity or belief in circumstances where publication of the answer was either automatic or very probable. Such questions could be asked in secret if the committees agreed not to identify specific individuals and groups when making their findings public. When a pledge of secrecy was extended, refusal to answer would be punished as contempt regardless of the subject with which the question dealt, so long as other statutory and constitutional requirements, such as pertinency, ${ }_{105}^{155}$ proper authority, ${ }^{150}$ and no self-incrimination ${ }^{157}$ were observed.

The solution offered is a limited one. A committee intent on exposure could still hold political inquisitions that the courts would be powerless to reach. But such practices would be unlikely in the face of a clear Supreme Court definition of the limits the First Amendment places on public legislative investigation. Such a holding would undoubtedly weigh heavily with responsible state and federal legislators who would seek to implement its policy in situations beyond judicial purview.

155. E.g., United States v. Rumely, 345 U.S. 41 (1953) ; Bowers v. United States, 202 F.2d 447 (D.C. Cir. 1953) ; United States v. Kamin, 136 F. Supp. 791 (D. Mass. 1956).

156. E.g., Kilbourne v. Thompson, 103 U.S. 168 (1880) (committee lacked authority to compel testimony because created for an improper purpose); Greenfield v. Russel, 292 III. 392,127 N.E. 102 (1920) (taxpayer enjoins payment of funds to a committee because it was performing improper function).

157. E.g., Emspak v. United States, 349 U.S. 190 (1955) ; United States v. Doto, 205 F.2d 416 (2d Cir. 1953); Marcello v. United States, 196 F.2d 437 (5th Cir. 1952).

The privilege against self-incrimination has been the most effective legal limit on the scope of committee inquiry to date. EMERSON \& HaBer, op. cit. supra note 136, at 454. But under the Immunity Act of 1954, 68 STaT. 745, 18 U.S.C. $\$ 3486$ (a),(b) (Supp. II, 1954). Congressional committees may be able to remove the self-incrimination privilege by extending immunity from prosecution for the matters the witness is compelled to disclose. Immunity can only be extended if two-thirds of the full committee affirmatively vote to authorize it and the local district court approves. The Attorney General may oppose the committee's motion in the district court.

The Supreme Court affirmed the constitutionality of the Immunity Act as applied to a recalcitrant grand jury witness, but did not consider the sections of the act dealing with investigating committees. Ullman v. United States, 24 U.S.L. WEER 4147, 4150 n.7 (U.S. Miar. 26, 1956). 